ANL/EAIS/TM- -60

DE92 003211

ANLEAIS/TM-60

\title{
The 1991 Department of the Army Service Response Force Exercise: Procedural Guide SRFX-91
}

by M.A. Madore, R.S. Thomson, R.A. Haffenden, T.E. Baldwin, and S.A. Meleski

Environmental Assessment and Information Sciences Division,

Argonne National Laboratory, 9700 South Cass Avenue, Argonne, Illinors 60439

September 1991

Work sponsored by U.S. Department of the Army,

Office of the Assistant Secretary, Installations, Logistics and Environment, Washington, D.C.

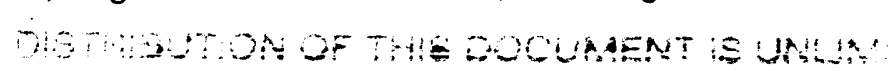




\section{CONTENTS}

FOREWORD $\ldots \ldots \ldots \ldots \ldots \ldots \ldots \ldots \ldots \ldots \ldots \ldots \ldots \ldots \ldots \ldots \ldots$ vii

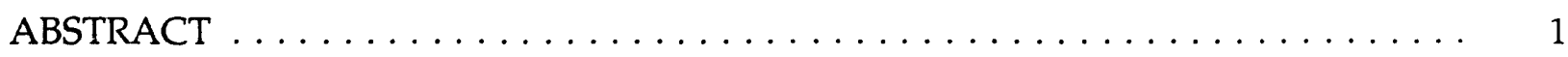

1 INTRODUCTION $\ldots \ldots \ldots \ldots \ldots \ldots \ldots \ldots \ldots \ldots \ldots \ldots \ldots \ldots \ldots$

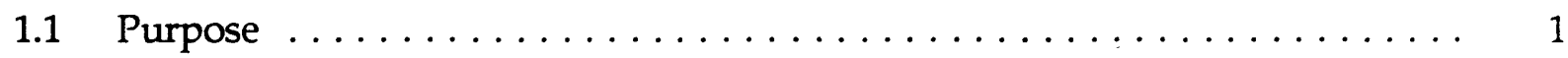

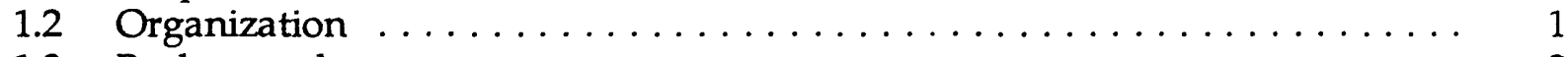

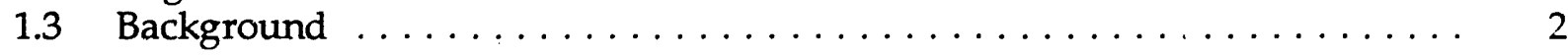

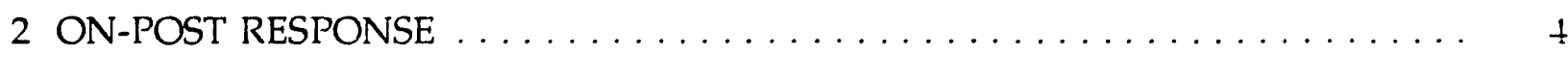

2.1 Chemical Accident Response by TEAD $\ldots \ldots \ldots \ldots \ldots \ldots \ldots \ldots \ldots \ldots$

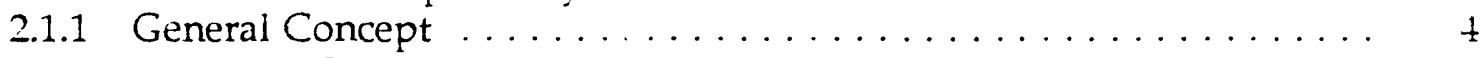

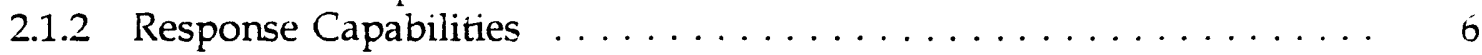

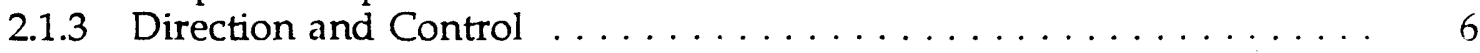

2.1 .4 Communications . . . . . . . .

2.1.5 Hazard Assessment . . . . . . . . . . . . . .

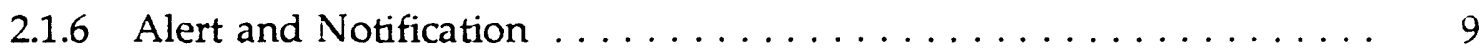

2.1.7 Protective Actions . . . . . . . . . . . . . . . . . . 10

2.1.8 Health and Medical Services . . . . . . . . . . . . . . 10

2.1 .9 Mass Care . . . . . . . . . . . . . . . . . . . . . 12

2.1.10 Field Operations/Emergency Worker Exposure Control . . . . . . . 12

2.1.11 Traffic and Access Control . . . . . . . . . . . . . . . . . . . 14

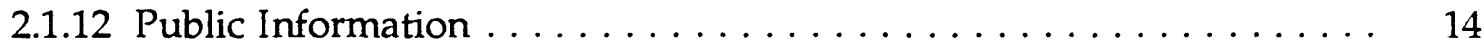

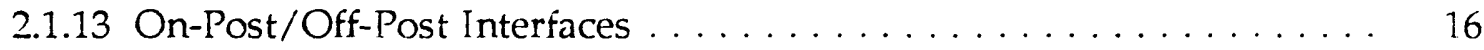

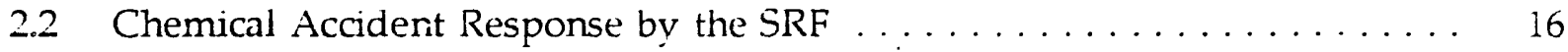

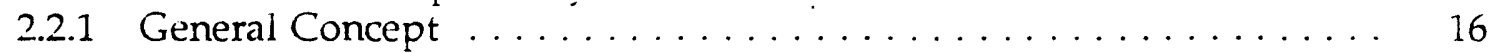

2.2 .2 Response Capabilities ...................... 20

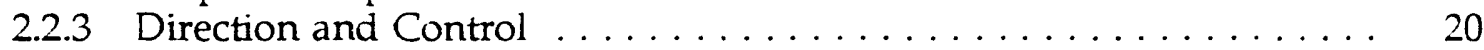

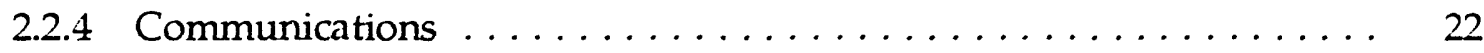

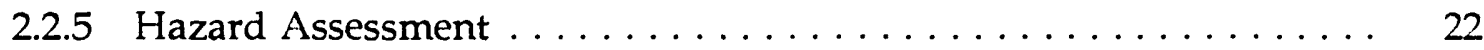

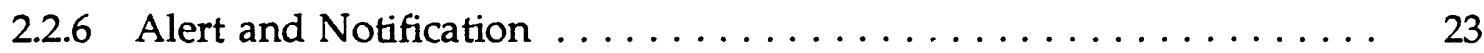

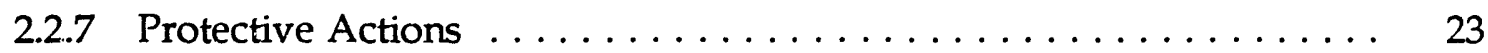

2.2 .8 Health and Medical Services ................... 23

2.2 .9 Mass Care . . . . . . . . . . . . . . . . . . . 24

2.2.10 Field Operations/Emergency Worker Exposure Control . . . . . . . 24

2.2.11 Traffic and Access Control . . . . . . . . . . . . . . . . 26

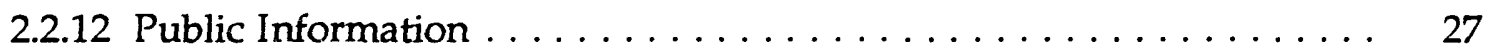

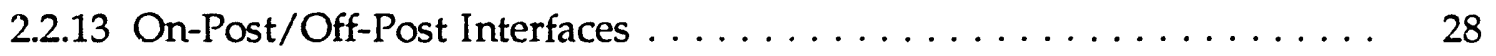

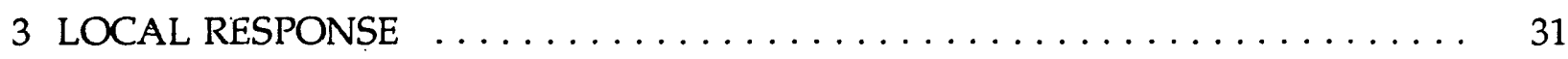

3.1 Chemical Accident Response by Tooele County . . . . . . . . . . . . 31

3.1 .1 General Concept . . . . . . . . . . . . . . . . . . . 31

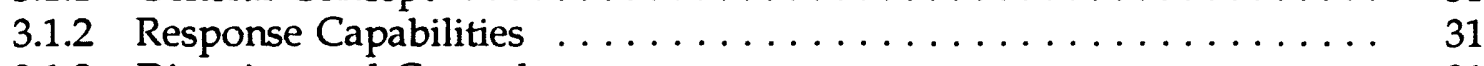

3.1.3 Direction and Control $\ldots \ldots \ldots \ldots \ldots \ldots \ldots \ldots \ldots \ldots \ldots \ldots \ldots$ 


\section{CONTENTS (Cont'd)}

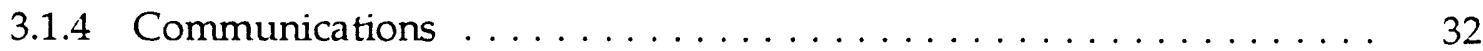

3.1 .5 Hazard Assessment . . . . . . . . . . . . . . . . . . . . . 32

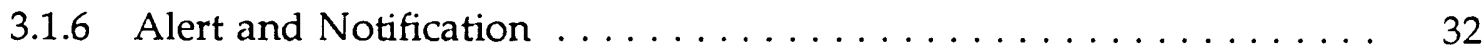

3.1 .7 Protective Actions ........................ 34

3.1 .8 Health and Medical Services $\ldots \ldots \ldots \ldots \ldots \ldots \ldots \ldots \ldots \ldots \ldots$

3.1 .9 Mass Care . . . . . . . . . . . . . . . . . . . . . . . 35

3.1.10 Field Operations/Emergency Worker Exposure Control . . . . . . . 36

3.1.11 Traffic and Access Control . . . . . . . . . . . . . . . . . . 36

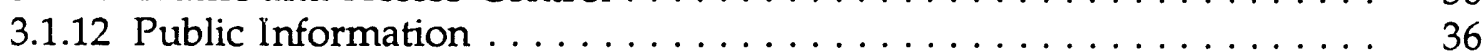

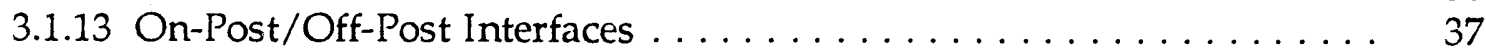

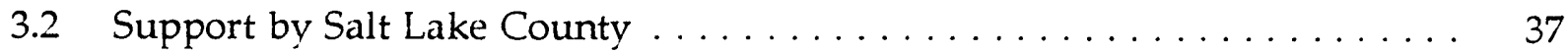

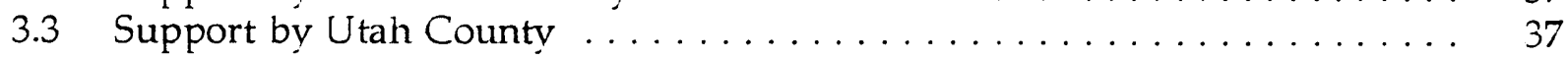

4 RESPONSE AND SUPPORT BY THE STATE OF UTAH . . . . . . . . . . 39

4.1 General Concept . . . . . . . . . . . . . . . . . . . . . . . . . . 39

4.2 Response Capabilities . . . . . . . . . . . . . . . . . . . . . . . . . 39

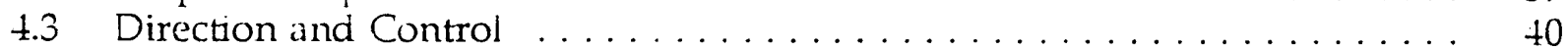

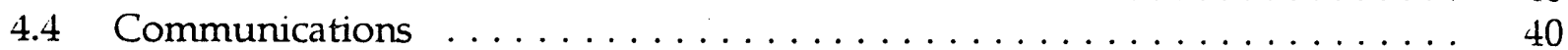

4.5 Hazard Assessment . . . . . . . . . . . . . . . . . . . . . . . 40

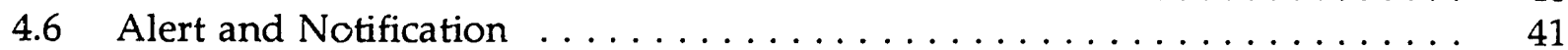

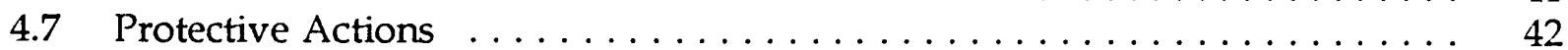

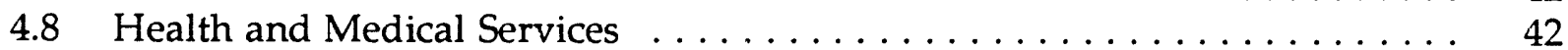

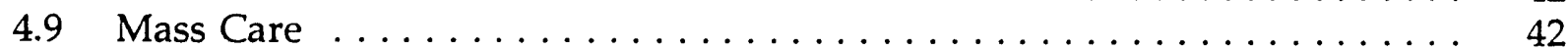

4.10 Field Operations/Emergency Worker Exposure Control . . . . . . . . . . 43

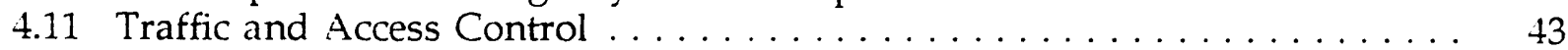

4.12 Public Information . . . . . . . . . . . . . . . . . . . 43

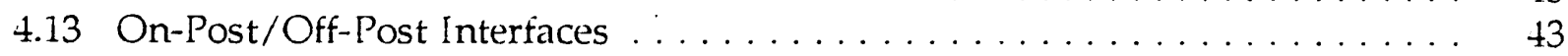

5 RESPONSE AND SUPPORT BY THE REGIONAL RESPONSE TEAM $\ldots \ldots \ldots$

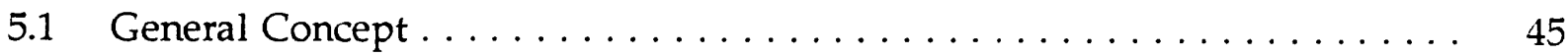

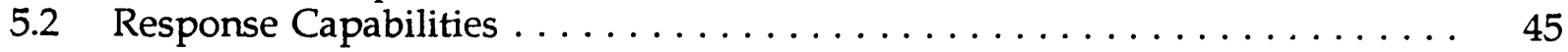

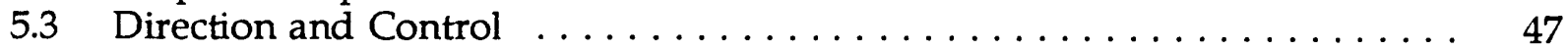

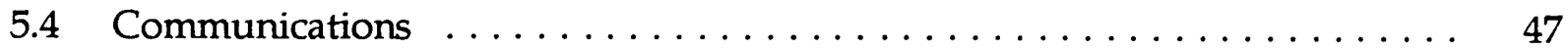

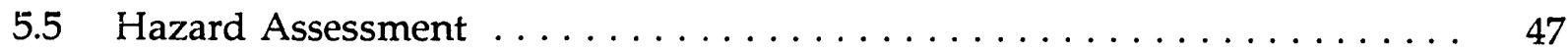

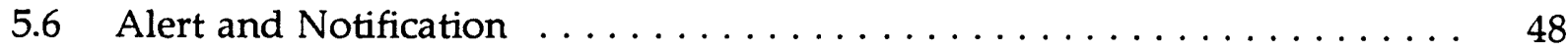

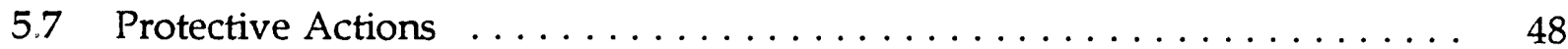

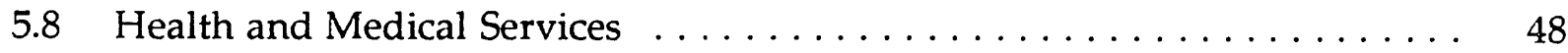

5.9 Mass Care . . . . . . . . . . . . . . . . . . . . . . . . . 49

5.10 Field Operations/Emergency Worker Exposure Control . . . . . . . . . . 49

5.11 Traffic and Access Control . . . . . . . . . . . . . . . . . . . . . . 49

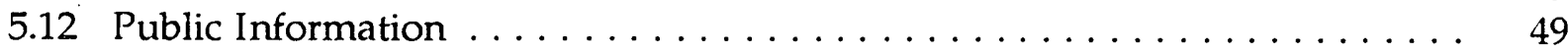

5.13 On-Post/Off-Post Interfaces $\ldots \ldots \ldots \ldots \ldots \ldots \ldots \ldots \ldots \ldots \ldots$ 
6 RESPONSE AND SUPPORT BY THE NATIONAL RESPONSE TEAM $\ldots \ldots \ldots \quad 50$

6.1 General Concept ........................... 50

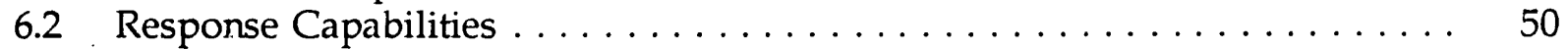

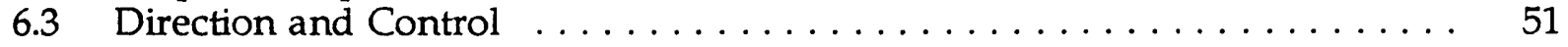

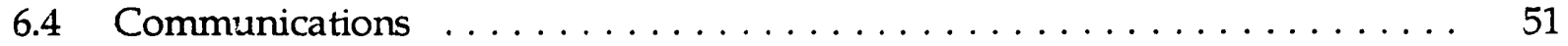

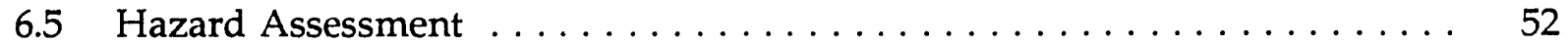

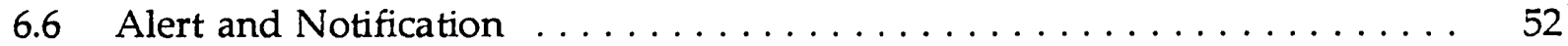

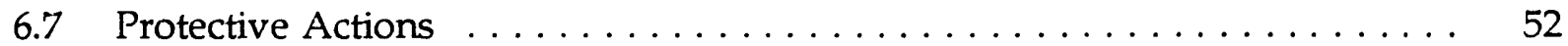

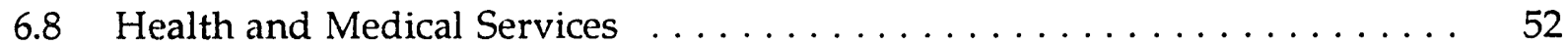

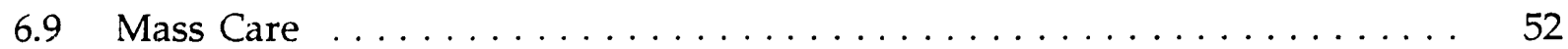

6.10 Field Operations/Emergency Worker Exposure Control $\ldots \ldots \ldots \ldots .53$

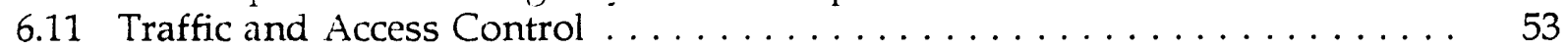

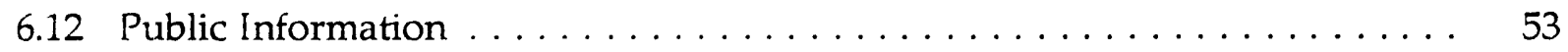

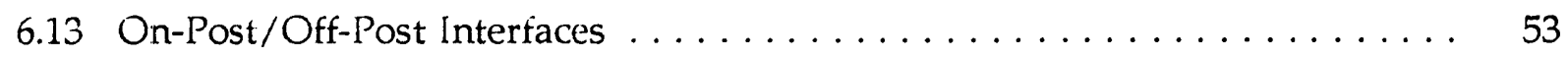

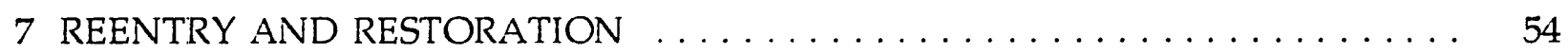

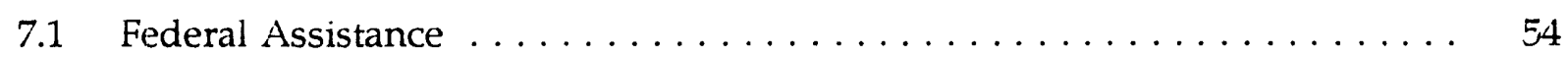

7.1.1 NRT/RRT Assistance .......................... 54

7.1.2 Department of the Army ....................... 55

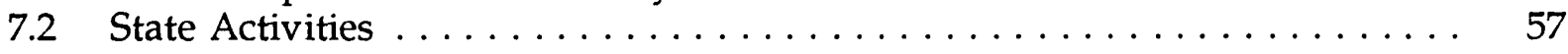

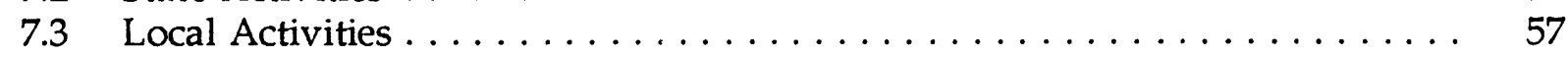

APPENDIX A: Environmental Statutes, Regulations, and Permit Requirements ........................... 59

APPENDIX B: Sources of Information $\ldots \ldots \ldots \ldots \ldots \ldots \ldots \ldots \ldots \ldots \ldots \ldots \ldots$

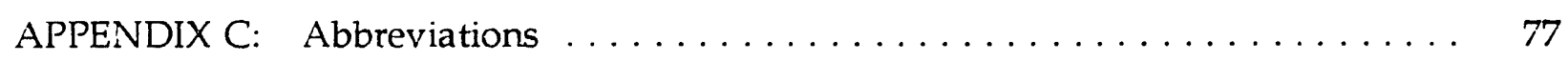

\section{FIGURES}

1 Chemical Accident Response Timeline $\ldots \ldots \ldots \ldots \ldots \ldots \ldots \ldots \ldots \ldots$

2 Tooele Army Depot and the Surrounding Area $\ldots \ldots \ldots \ldots \ldots \ldots$

3 Alert and Notification Fan-Out Chart $\ldots \ldots \ldots \ldots \ldots \ldots \ldots \ldots \ldots \ldots \ldots$

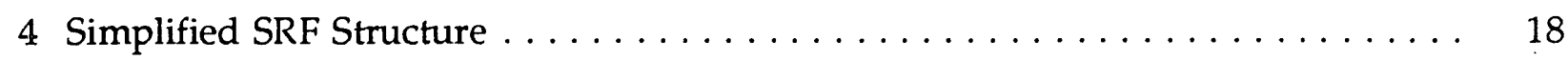




\section{TABLES}

1 TEAD Radio Control Stations for Accident Response . . . . . . . . . . . . 8

2 TEAD/Off-Post Interfaces $\ldots \ldots \ldots \ldots \ldots \ldots \ldots \ldots \ldots \ldots$

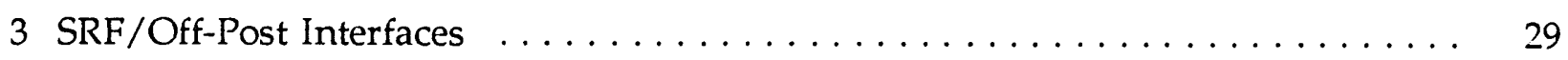

4 On-Post/Tooele County Interfaces $\ldots \ldots \ldots \ldots \ldots \ldots$

5 On-Post/State of Utah Interfaces $\ldots \ldots \ldots \ldots \ldots \ldots \ldots \ldots \ldots$

6 On-Post/RRT Interfaces $\ldots \ldots \ldots \ldots \ldots \ldots \ldots \ldots \ldots \ldots \ldots$ 


\section{FOREWORD}

As part of its energy system assessment program, Argonne National Laboratory's Environmental Assessment and Information Sciences Division conducts emergency and contingency planning for energy production facilities and other industrial installations. The Division plans and develops guidance for emergency preparedness and participates in the planning and execution of emergency response exercises. The Division has provided emergency planning for nuclear power plants, nuclear materials production facilities, and other facilities that produce or handle hazardous materials. Emergency planning projects are sponsored by federal agencies such as the Federal Emergency Management Agency, the U.S. Department of Defense, and the U.S. Department of Energy and its contractors.

This report documents Argonne's analysis of preparedness and response plans, as provided to the U.S. Army Materiel Command in preparation for an emergency exercise. The exercise was conducted by the Service Response Force, which is maintained and deployed by the U.S. Army to assist army installations in responding to chemical weapons accidents that threaten the public health or safety. The chemical emergency exercise discussed in this report was conducted in June 1991 at Tooele Army Depot near Salt Lake City, Utah. This report is substantively identical to material provided to the U.S. Army in May 1991 for pre-exercise planning and training. 


\title{
THE 1991 DEPARTMENT OF THE ARMY \\ SERVICE RESPONSE FORCE EXERCISE:
}

\author{
PROCEDURAL GUIDE SRFX-91
}

by

\author{
M.A. Madore, R.S. Thomson, R.A. Haffenden, T.E. Baldwin, and S.A. Meleski
}

\begin{abstract}
This procedural guide was written to assist the U.S. Army in planning for a chemical emergency exercise at Tooele Army Depot in Utah. The roles of various members of the emergency response community are described for various accident scenarios, and the relationships between the various responders are identified. For the June 1991 exercise at Tooele, the emergency response community includes the command structure at Tooele Army Depot; the U.S. Army Service Response Force and other Department of Defense agencies; emergency response personnel from Tooele, Salt Lake, and Utah counties and municipal governments; the Utah Comprehensive Emergency Management Agency and other state agencies; and various federal agencies.
\end{abstract}

\section{INTRODUCTION}

\subsection{PURPOSE}

The purpose of this procedural guide is to identify those Army, U.S. Department of Defense (DOD), and other government and nongovernment agencies constituting the emergency management community poised to respond to a chemical accident at the Tooele Army Depot (TEAD) in Tooele County, Utah. The responsibilities, functions, and capabilities of each member of the response community are described, and the interaction ("interface") between and among these agencies is delineated. This guide is to be used as a planning and training aid for the Army's Chemical Service Response Force Exercise (SRFX) scheduled for June 1991 (SRFX-91).

Information contained in this guide has been derived from analysis of currently available plans from the appropriate emergency organizations. However, as most of the plans analyzed are undergoing revision, it is expected that some of the information in this guide will be outdated by the time SRFX-91 is conducted.

\subsection{ORGANIZATION}

This guide is organized so that the first responders and their action plans are described first, followed by the next level of government to become involved and so forth in the sequence that would be most likely to occur. Therefore, the on-post response is described in Section 2 , 
with the plans specific to TEAD analyzed first in Section 2.2 and the more general, systemwide plans for the Army's Service Response Force (SRF) in Section 2.3. Section 3 describes the local response, that is, current Tooele County plans for response to an accident at TEAD. Also described are the expected actions of the two primary support counties, Salt Lake County and Utah County. In the event that the resources of Tooele County become overwhelmed by the impact of an chemical incident at TEAD, the state of Utah will provide additional support as outlined in Section 4.

Also available for the provision of resources and technical advice and guidance are the Regional Response Team (RRT) and the National Response Team (NRT), as promulgated under the National Oil and Hazardous Substances Pollution Contingency Plan (NCP). The plans, requirements, and resources associated with these teams are described in Sections 5 and 6 for regional and national assistance, respectively. Finally, the resources available for reentry and restoration after an accident are summarized in Section 7.

Appendix A contains information on applicable environmental statutes, regulations, and permit requirements. Appendix $B$ lists the plans that were reviewed and analyzed, as well as pertinent statutes and regulations. Finally, Appendix $C$ lists the abbreviations used in this guide.

A chemical accident response timeline (Figure 1) has been developed to summarize some of the most significant activities occurring during a response. The timeline is an estimation of the sequence and timing of key events, and it provides an overview of the anticipated actions by organizations responding to a chemical accident at TEAD.

Each major section of this guide begins with the general concept for response by that agency or level of government, followed by a summary of its response capabilities. These functional capabilities are described more fully in sections on direction and control, communications, hazard assessment, alert and notification (including mobilization of emergency organizations and notification of the public), protective actions, health and medical services, mass care, field operations/emergency worker exposure control, traffic and access control, public information, and on-post/off-post interfaces (typically provided in a tabular format).

\subsection{BACKGROUND}

The SRF is a force of Department of the Army (DA) personnel from around the country that responds to accidents that involve Army chemical warfare agents and exceed on-post response capabilities. This force, which is commanded by a general officer, comprises a crisis management unit, portions of the installation-based Initial Response Force (IRF), emergency medical personnel, explosives ordnance disposal (EOD) teams, communications personnel, and other Army technical specialists and response units that might be needed. A Service Response Force Exercise is a real-time response of the SRF to a simulated chemical agent accident on an installation with a chemical surety mission (i.e., to ensure the safety and reliability of chemical munitions). The SRFX executes the mandate, in Army Regulation 50-6 (AR 50-6), to maintain and exercise the chemical SRF biennially. The Army's first SRFX was conducted in 1985. In recent years, the participation of off-post officials and organizations in SRFXs has increased. Significant off-post participation is expected for SRFX-91. 


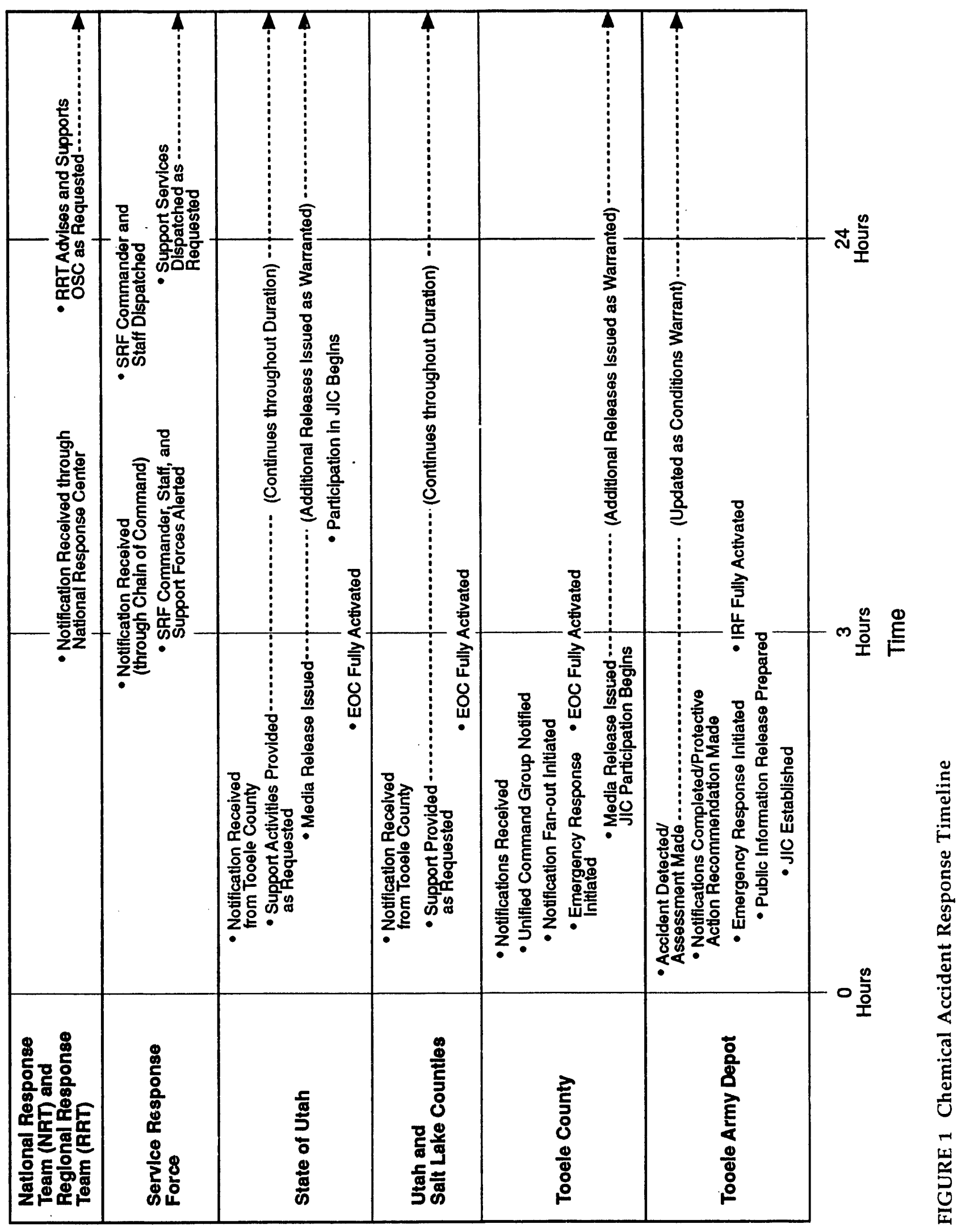




\section{ON-POST RESPONSE}

This section describes the response capabilities and activities of TEAD's Initial Response Force and the Army's (DA's) Service Response Force.

\subsection{CHEMICAL ACCIDENT RESPONSE BY TEAD}

This section describes the response of TEAD to a chemical accident* occurring within or near the installation. The discussion was derived from a review and analysis of the draft Tooele Army Depot Disaster Control Plan (TEAD-DCP), Annex C, Chemical Accident/Incident Response and Assistance Plan (CAIRAP), dated January 28, 1991. Figure 2 is a simplified map of TEAD and the surrounding area.

\subsubsection{General Concept}

The installation's IRE is activated as the first line of response to a chemical accident at TEAD. The IRF is organized into three groups: the Response Group, the Support Group, and the Command Group. The Response and Support Groups report to the Command Group. The Command Group, under the direction of the IRF Commander (referred to as the IRFC in the TEAD-DCP), directs the Chemical Accident/Incident Response and Assistance (CAIRA) operations; the Installation Commander serves as the IRF Commander. The Response Group, the principal response organization, is subdivided into four task groups:

1. Field Command Post (FCP): A location in the TEAD South Area (Building S-5108) from which all CAIRA operations are controlled.

2. Emergency Operations Center (EOC): A location (Building $\mathrm{T}-1$ ) that serves as headquarters for the Command Group and provides support and backup for the FCP.

3. Forward Control Site (FCS): A forward command center to control operations in the field, as directed by the FCP. The FCS is established adjacent to the Hotline, an upwind demarcation that geographically separates a contaminated area from a contamination-free area. The FCS controls entry to and egress from a chemical accident site.

4. Augmentation Response Element: This task group provides additional personnel and equipment as needed.

The Support Group provides services and supplies to the Command and Response Groups.

\footnotetext{
*The term "chemical accident" has been selected for use throughout this guide to refer to the unintended release of chemical agent into the atmosphere. This usage is intended to reduce the potential for confusion over which term is appropriate and to ensure that all parties (military and civilian) involved in the planning of SRFX-91 use familiar terminology. This usage applies only to this document and does not represent a change in existing Army policy or practice regarding accepted terminology.
} 


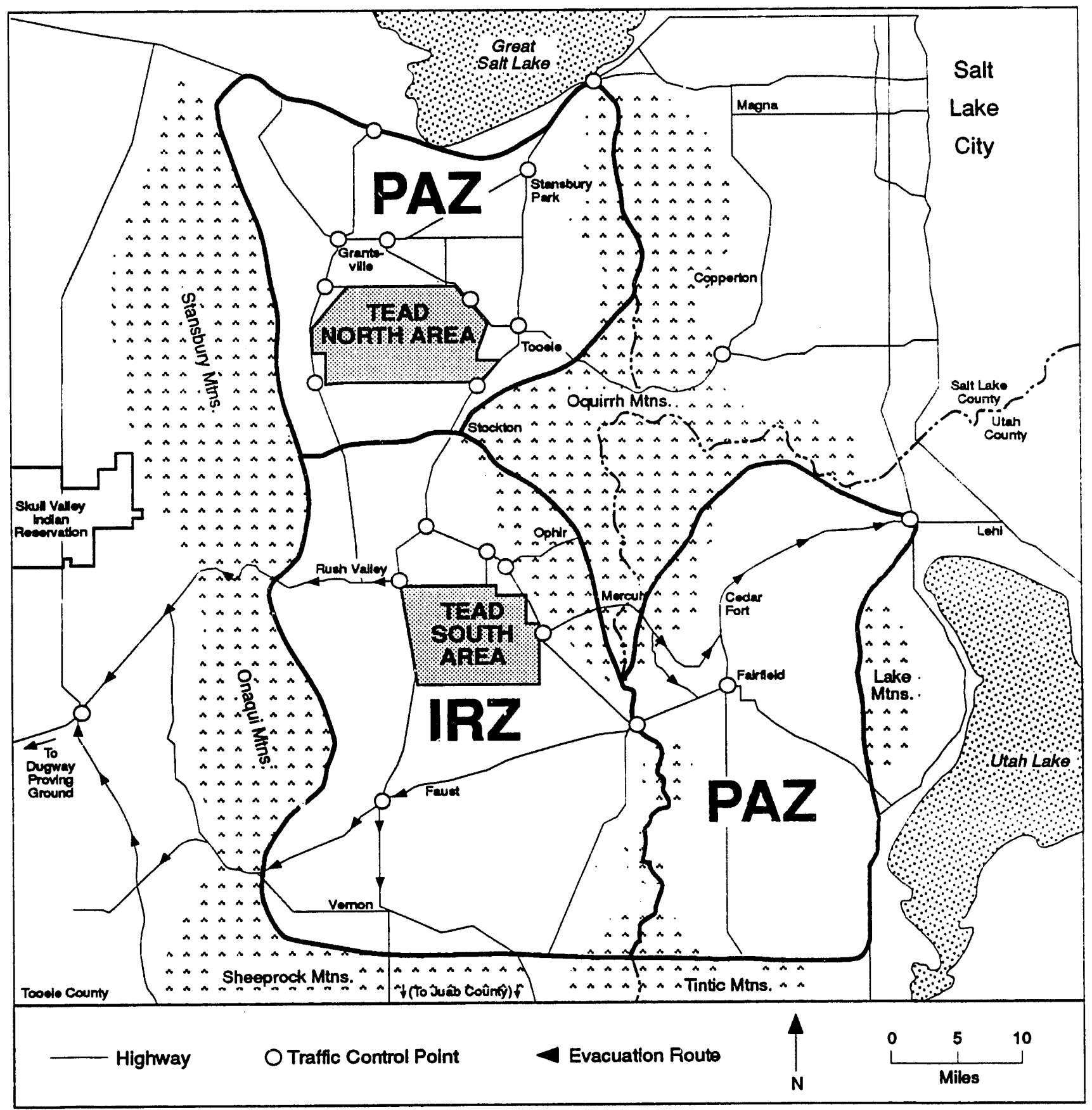

FIGURE 2 Tooele Army Depot and the Surrounding Area 
The IRF is activated immediately when it has been determined that an accident has occurred. It is the goal of the IRF to be able to immediately carry out CAIRA operations with little or no notice. Depending upon the severity of the accident, the IRF may be capable of handling all phases of a CAIRA operation without involving the SRF. However, should an accident require a level of emergency response that exceeds the capabilities of the IRF, the SRF will be activated. When the SRF Commander (or SRFC) arrives and assumes command, the IRF is absorbed into the SRF under command of the SRF Commander. A key principle of the SRF concept is that the IRF is not displaced by the SRF. Rather, the SRF consists of the IRF plus additional resources, thereby increasing the resources of the IRF.

\subsubsection{Response Capabilities}

The IRF must be capable of immediately and effectively responding to chemical accidents. To accomplish its mission, the IRF must be capable of performing the following functions: (1) prepare for and deploy to the accident site; (2) upon determining that an accident has occurred, respond to the emergency and perform emergency operations; (3) when the emergency has been stabilized, initiate activities to restore, as feasible, conditions at the accident site; (4) as appropriate, transfer responsibility for restoration operations to the Installation Restoration Program (IRP); and (5) facilitate the withdrawal of military and civilian emergency response elements from the accident site.

As the first responding force, the IRF has the following unique responsibilities:

1. Assess the hazard and determine the emergency notification level (i.e., emergency classification level).

2. Notify local and state authorities in a timely manner.

3. Initiate protective actions for on-post personnel and recommend protective actions for the off-post public.

4. Commit installation assets, if available and requested, to assist in the offpost response to the accident.

5. Serve as the primary point of contact for off-post officials until arrival of the SRFC.

6. Notify the National Response Center (NRC) and the Army Operation Center (AOC).

\subsubsection{Direction and Control}

The IRF Commander, for purposes of NCP requirements, also serves as the On-Scene Coordinator (OSC) until these duties are assumed by the SRF Commander. Until replaced by the SRF Commander, the TEAD Installation Commander is the IRF Commander and the senior military official present at the accident site. In this capacity, he or she represents DOD, as well as DA, and has operational control of all military forces and operations at the accident location. As the senior DOD representative present, the IRFC has direct access to the highest levels of DA 
or DOD and has the authority to request the necessary emergency response support, including coordination with the Commander of the U.S. Army Materiel Command (AMC) in recommending activation of the SRF. The EOC serves as a command post and control point for the IRF Commander and his or her staff.

As the OSC, the IRF Commander coordinates and directs the federal response to a hazardous substance, pollutant, or contaminant release. Until the SRF Cominander assumes command, the IRF Commander is the point of contact for the coordination of state and local response with the federal response effort. The OSC is also a source of federal resources beyond those provided by the DOD that can be made available to support the state and local response.

\subsubsection{Communications}

The communications systems used in support of chemical accident operations at TEAD are described in Appendix VIII, Information System Support, and Appendix V, Notification System, of the TEAD-DCP. When it has been determined that a chemical accident has occurred, on-post telephone and radio traffic will be restricted to calls and messages required to deal with the situation. The TEAD radio network consists of the Radio Control Stations given in Table 1. operations:

The TEAD-DCP recommends the following telephone service to support emergency

- Class A (DSN/off-base access) telephone lines with associated telephone instruments (actual quantity optional, as necessary to support requirements)

- Class A (DSN/off-base access) telephone line(s) with connection for data modem (as required)

- Local telephone company business line with associated telephone instrument (as required)

The primary means of communication between TEAD and off-post officials and organizations is commercial telephone. TEAD has access to the Statewide Law Enforcement Radio Band and will use it as a backup.

\subsubsection{Hazard Assessment}

The responsibility for hazard assessment rests with the IRF until the SRF is in place. The TEAD Surety Officer is responsible for ensuring that, in the event of a chemical accident, a Chemical Accident/Incident Control Officer (CAICO) is available who will be responsible for evaluating the situation based upon data furnished from the accident site arid determining the correct course of action. The Director of Installation Operations is responsible for providing representatives to the EOC from the Environmental Office to assess a hazarcious substance spill. These personnel report to the Director or Risk Assessment, who functions as the FCP Commander. 
TABLE 1 TEAD Radio Control Stations for Accident Response

\begin{tabular}{llcl}
\hline Control Station & Personnel & $\begin{array}{c}\text { Radio } \\
\text { Channel }^{\text {a }}\end{array}$ & \multicolumn{1}{c}{ Vehicle } \\
\hline AAG-441 South & $\begin{array}{l}\text { South Area } \\
\text { Security } \\
\text { Elements }\end{array}$ & 1 & Security South \\
AAG-441 North & $\begin{array}{l}\text { North Area } \\
\text { Security } \\
\text { Elements }\end{array}$ & 3 & Security North \\
AAG-415 North & $\begin{array}{l}\text { South Area, } \\
\text { FCP and }\end{array}$ & 2 & Chemical \\
CAICO & $\begin{array}{l}\text { North Area, } \\
\text { EOC }\end{array}$ & 2 & Chemical \\
AAG- +45 & $\begin{array}{l}\text { Medical and } \\
\text { fire teams }\end{array}$ & 4 & Fire/Medical \\
\hline
\end{tabular}

${ }^{\mathrm{a}}$ For hand-held radios.

The Director of Supply is responsible for providing qualified personnel to perform and maintain an accurate inventory of chemical surety materiel at the installation and to provide one person trained to perform downwind hazard calculations. The Director of Ammunition Operations provides three additional personnel trained in downwind hazard calculation techniques to support the EOC. The Safety Officer is responsible for immediately advising the IRF Commander of any unsafe or potentially unsafe act, procedure, or condition that could contribute to an accident. During a chemical accident, the Safety Officer is responsible for maintaining an open telephone line between the FCP and EOC for collecting and exchanging data for incident reporting requirements.

Off-post state and Tooele County response organizations will receive information from the installation on the assessment of the hazard, but will not participate in evaluation of the chemical accident. Hazard assessment will be performed only by on-post personnel who are equipped with appropriate protective gear and who have specialized assessment equipment. Communication between the IRF Commander and local public officials during an accident will include complete accident assessment iriormation so that local officials can recommend appropriate protective actions to the public. 


\subsubsection{Alert and Notification}

The hazard assessment results in the determination of a hazard classification. The chemical accident/incident $(C A / I)$ system set forth in the TEAD-DCP (Appendix V, Tabs A-F) defines three* CA/I Phases:

- Phase I, Limited Area Emergency - Off site notification not normally necessary.

- Phase II, Post-Only Emergency - With approval of the Installation Commander or designee, notification of officials of potentially affected counties.

- Phase III, Community Emergency -- Mandatory notification of affected areas in the Immediate Response Zone (IRZ, see Figure 2).

The CA/I Phases in the TEAD-DCP correspond to the Emergency Classification Levels (ECLs) described in the Tooele County plan.

On-post organizations are notified by telephone, radio, or both according to the $\mathrm{CA} / \mathrm{I}$ Phase. During normal duty hours, on-post organizations are notified of a chemicai accident via the on-post AMMO Radio Network. During nonduty hours, the Staff Duty Officer/ Noncommissioned Officer (NCO) is responsible for directing the notification of on-post organizations.

If it becomes necessary to evacuate the post, TEAD will activate the South Area evacuation sirens located at Buildings 5010 and 4553, Site Security Control Center (SSCC) Area 10, the SSCC Chemical Agent Munitions Disposal System (CAMDS) Site, and the Chemical Stockpile Disposal Program (CSDP) Construction Site. The siren system will normally be activated from the FCP, although the system can be activated from each of the facilities where sirens are located.

The IRF Commander, or his or her designee, is responsible for approving the notification of local and state authorities of a chemical accident in a timely manner. TEAD will directly notify the Tooele County Sheriff's Office through the Statewide Law Enforcement Radio Band or the Utah State Comprehensive Emergency Management (CEM) Repeater Network. The Sheriff's Office is responsible for notifying other off-post agencies and officials. A standard notification form is available for use, and it will provide essential information such as the CA/I Phase (or ECL), areas affected or potentially affected, and protective action recommendations.

The decision to alert the public for any CA/I Phase rests with off-post public officials. However, under the most extreme circumstances, it may be necessary to alert the public directly from TEAD. This action would be evaluated on a case-by-case basis, after discussions with members of the Tooele County Unified Command Group, and carried out only when it is

\footnotetext{
*A fourth CA/I Phase, Non-Surety Emergency, has not yet been incorporated into the TEAD-DCP, and it may not be used during SRFX-91. The Non-Surety Emergency may be declared when events are likely to occur or have occurred that pose no chemical hazard but may be perceived as a chemical surety emergency or that may be of generai pubilic interest.
} 
deemed absolutely necessary to protect the public health and safety. Should direct public alerting be deemed necessary, it would be accomplished two ways: through the media (see Section 2.1.12) and through direct route alerting. Direct route alerting will be coordinated with the Tooele County Sheriff's Office augmented by the on-post security force. The security force on the installation is large enough to execute direct route alerting. The Sheriff's Office may decide to telephone some residents to supplement the route alerting, especially before the siren system or tone alert radio system is activated.

The alert and notification chart (Figure 3) indicates which organizations are notified by TEAD and other organizations.

\subsubsection{Protective Actions}

The IRF Commander, or his or her designee, is ultimately responsible for recommending protective actions for the public to local officials, who in turn must make the decisions as to which actions are to be taken based upon the information they are given as well as their independent assessment of the situation. The IRF Commander is advised by the CAICO, who is responsible for evaluating the situation and determining the correct course of action (i.e., sheltering or evacuation) based upon data furnished from the accident site. The CAICO's determination will be based, in part, upon technical input provided by the hazard assessment team at the EOC.

Whenever possible, the decision to take protective actions (e.g., evacuation) is to be made by local public officials based upon recommendations provided to them by the IRF Commander or his or her designated representative. However, in the event of a Community Emergency (CA/I Phase III) when there is insufficient time to recommend protective actions, it may be necessary for the IRF Commander, or his or her designated representative, to issue immediate protective actions directly to the public in affected areas (i.e., direct route alerting) and to discuss this action with public officials after issuing the protective action notification. However, as discussed in the previous section, the TEAD security force would coordinate with and augment the Sheriff's Office personnel in all but the most severe accident scenario.

\subsubsection{Health and Medical Services}

The Director of the TEAD U.S. Army Health Clinic is responsible for maintaining liaison with local medical facilities regarding the treatment of chemical agent casualties. With the IRF Commander's approval, the Director may request additional medical support to treat on-post casualties. The Post Surgeon is responsible for ensuring coordination relative to chemical accidents with the professional medical staffs of the following hospitals:

- Tooele Valley Regional Medical Center, Tooele

- LDS Hospital, Salt Lake City

- University of Utah Medical Center, Salt Lake City

- Holy Cross Hospital, Salt Lake City 


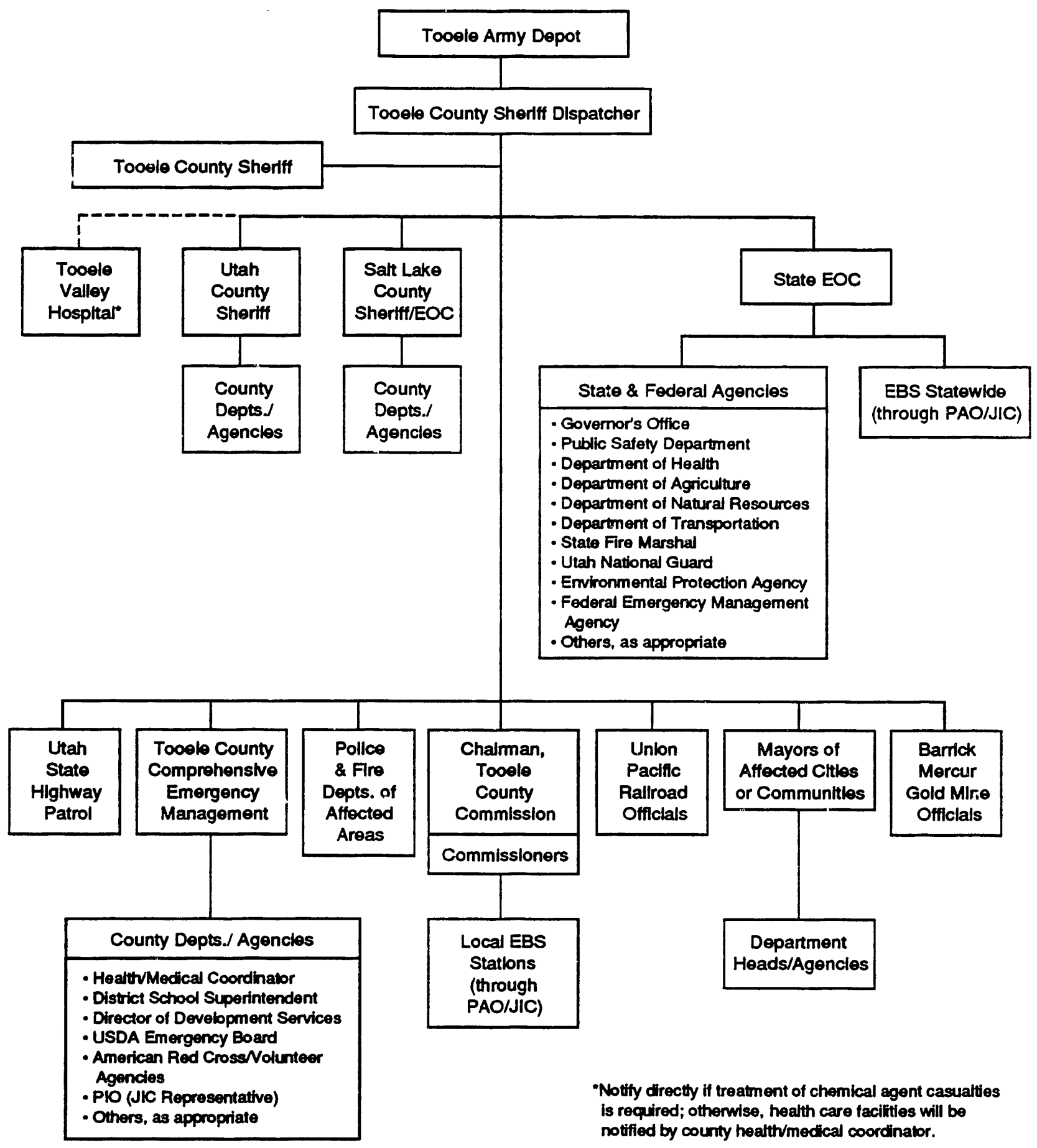

FIGURE 3 Alert and Notification Fan-Out Chart 
The EOC Commander, or his or her designated representative, is responsible for notifying the TEAD Health Clinic of off-post hazards. The ranking Health Technician on duty, when so notified of a chemical accident affecting off-post areas and after given approval by the IRF Commander, immediately (1) notifies the TEAD Health Clinic, (2) notifies the Senior Health Technician and other team members, and (3) prepares the installation's field response ambulance for off-post response. These limited TEAD medical and health resources will be available only after on-post requirements are satisfied. In the event there are casualties to individuals off-post, the Director advises local medical facilities to expedite the diagnosis of patients displaying symptoms of toxic poisoning.

\subsubsection{Mass Care}

If it becomes necessary to evacuate on-post personnel, evacuees from the Tooele South Area will be sent to the primary reception center at Lehi High School, about 25 miles east of TEAD on Highway 73.

\subsubsection{Field Operations/Emergency Worker Exposure Control}

The CAICO is responsible for coordinating with responsible officials at TEAD to ensure that CAIRA emergency teams are organized and trained to meet the needs of the installation. As a key element of the IRF, this individual is responsible for the control, confinement, and neutralization of the chemical accident. The CAICO is assigned to the FCP and is responsible for directing and deploying specialized teams as may be required for this purpose. Performing in this capacity, this individual has the authority to commandeer for emergency response any military/federal government equipment that is immediately available. The CAICO exercises control of all accident site evacuations, emergency rescues, and decontamination operations. The $\mathrm{CAICO}$ is also responsible for the following field activities:

- Determining the areas of possible contamination and ensuring that danger areas are properly marked or identified,

- Requesting additional on-post assistance through the EOC,

- Assisting the IRF Commander in determining the need for outside assistance, and

- Determining that the accident site has been rendered safe and free of contamination and advising the IRF Commander when the accident site has been neutralized.

The following field operations responsibilities are assigned to key personnel who comprise the IRF Response Group.

The Director of Installation Operations is responsible for training South Area primary and backup fire fighting personnel and providing these personnel to identify and set up the Hotline during nonduty hours, fight a toxic chemical fire, and assist in fire rescue operations at an accident site. The Director of Installation Operations is also responsible for providing representatives from the Envirorımental Office to assess a hazardous substance spill. 
All TEAD Directors, Division Chiefs, and Special Staff are responsible for providing logistical and administrative support to off-post CAIRA teams that are dispatched to TEAD to assist in controlling chemical accidents.

The Director of Ammunition Operations is responsible for the rapid deployment, as directed by the CAICO, of a three-person initial response team, referred to as Meteorological Detection Team 1 (MET 1), directly to the accident site. This person is also responsible for providing the following field response personnel:

- An alternate Hotline Coordinator and a minimum of eight trained personnel who respond as an alternate or backup Hotline Team,

- Two personnel designated respectively as a primary and an alternate shower trailer operator, and

- Two decontamination teams.

The Chief of the Ammunition Surveillance Division is responsible for providing primary and alternate personnel to staff four Meteorological Detection/Decontamination Teams (METs 2, 3,4 , and 5). These monitoring teams are cross trained for decontamination duties as backup to the primary decontamination teams should the requirement for these operations become extencive.

The Director of the CAMDS is responsible for providing the following field personnel:

- A Primary Hotline Team, including a Coordinator and two alternates,

- Three personnel qualified to function as the Assistant CAICO (or ACAICO),

- Downvind hazard plotters for the EOC and FCP,

- Two meteorological detection teams (METs 6 and 7 ) for the Hotline and/or as backups for METs 2 through 5,

- Sufficient personnel to staff primary and backup decontamination teams at the Hotline, and

- A minimum of four backup personnel to drive ambulances.

During nonduty hours, the Security Shift Supervisor, in coordination with the Fire Department Shift Supervisor, is responsible for assuming control of the chemical accident Hotline until the CAICO arrives.

The Director of Law Enforcement and Security is responsible for deploying security staif to direct the evacuation of on-post personnel and to control access to the installation and accident site as required.

The Depot Photographer will respond as directed by the IRF Commander, Chief Counsel, or EOC Commander to provide photographic coverage of the accident site. 


\subsubsection{Traffic and Access Control}

The TEAD Directorate of Law Enforcement and Security is responsible for directing traffic during the evacuation of on-post personnel and for controlling access to the installation and accident site. The extent of the area to which access would be controlled will depend upon the severity of the accident. Where the accident is confined to the limited area on-post, Security Police will implement standing procedures. Where there are effects on-post outside the limited area, a temporary exclusion area will be established and access allowed only through an entry control point.

Where there are off-post consequences, a National Defense Area (NDA) may be established with the smallest perimeter possible to protect chemical surety materiel, safeguard classified defense information, and protect DOD equipment and materiel. Upon arrival at the accident site, the responding security officer wili assess the situation, including any ongoing emergency response operations or activities being carried out by local or state law agencies, and establish security at the site in cooperation with civil authorities. This coordination will include the following interface with federal, state, and local law enforcement officials:

- Coordinating as necessary with the Tooele County Sheriff's Office and the Utah Highway Patrol in implementing the Mutual Support Agreement.

- Maintaining liaison with the appropriate law enforcement agencies, including local, state, federal, and supporting military intelligence representatives.

- Providing gas masks to the Tooele County Sheriff's Office and the Utah Highway Patrol.

- Interfacing with the Tooele County Sheriff's Office and the Utah Highwav Patrol, which will direct traffic for civilian evacuation, provide roadblocks for access control and highway clearing, and control access of trail vehicles to accident sites.

\subsubsection{Public Information}

Upon notification of CA/I Phase I (Limited Area Emergency), the TEAD Public Affairs Officer (PAO), or designated alternate, will monitor response efforts. If the emergency escalates to CA/I Phase II (Post-Only Emergency), the PAO or alternate will report to the EOC and the Public Affairs Specialist will immediately notify the Public Affairs Support Staff to report to the TEAD Public Affairs Office. During initial response to a chemical accident, the Joint Information Center (JIC) will be located in Building 7 (North Area), the TEAD Training Center. ${ }^{*}$ The JIC is primarily a work area from which material to be presented at press briefings will be prepared.

\footnotetext{
*Although the TEAD-DCP indicates that the JIC will be located on-post, it is anticipated that, for the purposes of SRFX-91, the JIC will be located just outside the installation proper (North Area). Tooele County and the state of Utah will participate in JIC operations at that location.
} 
If a large number of media representatives are present for these briefings, they will be conducted in the Depot Theater.

The PAO is responsible for:

- When necessary in the interest of public safety, coordinating with local officials to alert the public through the media (e.g., to activate the Emergency Broadcasting System [EBS]),

- Coordinating all news releases and press briefings with the Legal Office,

- Coordinating the approval of releases and briefings with the EOC Commander and the IRF Commander,

- Preparing and issuing approved news releases,

- Conducting press briefings at TEAD (usually held in the Depot Theater), and

- Contacting the PAOs at the U.S. Army Depot System Command (DESCOM) and AMC (but only after the Installation Commander has made notifications through operational channels).

The TEAD-DCP includes eight fill-in-the-blank public news releases and three "rush" flier" bulletins for distribution to TEAD employees. These cover the following subjects:

- Evacuation of residents

- Death and injury -- no off-post hazard

- Minimum chemical accident -- no injury or off-post hazard

- Vehicular caused chemical accident, outside evacuation, dead and injured

- Vehicular caused accident, no evacuation, dead and injured

- Off-post vehicular accident, evacuation

- Off-post vehicular accident, no evacuation, no dead or injured

- Evacuation release

- Rush Flier -- evacuation, dead and injured

- Rush Flier -- no off-post hazard, dead and injured

- Rush Flier -- Minor chemical accident, hot off-post, no dead or injured 
Emergency Public Affairs Fly Away Kits have been prepackaged for use at the JIC and are stored in the Public Affairs Vault in the basement of Building T-1 (the EOC). The media kits contain information packets, portions of relevant Army regulations and the TEAD-DCP, and identification badges for the PAO staff and accredited media representatives.

As part of the Public Affairs Recovery Plan, the installation PAO will conduct the following activities after the emergency phase has been completed:

- Make follow-up visits to media to respond to unanswered inquiries and outline the restoration program and progress;

- Schedule briefings presented by knowledgeable installation representatives at community meetings; and

- Schedule briefings, no later than 2 weeks following a chemical accident, to be given by the IRF Commander to the Intergovernmental Consultation and Coordination Board, local mayors, and Tooele County Commissioners.

\subsubsection{On-Post/Off-Post Interfaces}

Table 2 describes the interfaces between TEAD personnel and off-post officials.

\subsection{CHEMICAL ACCIDENT RESPONSE BY THE SRF}

The material in this section describes (1) the mechanism for requesting the activation of the SRF, (2) the general response capabilities of the SRF, and (3) the structure and specific functional capabilities of the SRF. This information was derived from analysis of the AMC Chemical Service Response Force Commander's Emergency Response Plan (CSRFCERP).

\subsubsection{General Concept}

Under AR 50-6, the Commanding General of AMC is required to establish, train, arid maintain an SRF capable of responding to Army chemical accidents. The SRF is a DA-level emergency response force with a high level of expertise for dealing with chemical accidents. Under the structure of the SRF, the Army can bring together a number of diverse technical and support units, as needed, to sustain an extended response to a chemical accident. When accident resource demands exceed those available through the IRF, the IRF Commander will request additional assistance from the SRF.

The SRF is divided into four functional units: (1) the Command Group and Personal Staff, (2) the Special Staff Directorate, (3) the Operations Directorate, and (4) the Support Directorate. A brief description of each group follows. The overall SRF structure is depicted in a simplified organizational chart in Figure 4. 
TABLE 2 TEAD/Off-Post Interfaces

\begin{tabular}{ll}
\hline \multicolumn{1}{c}{ TEAD Position or Organization } & \multicolumn{1}{c}{ Interface Description } \\
\hline $\begin{array}{l}\text { IRF Commander (Installation Commander) or } \\
\text { designee }\end{array}$ & $\begin{array}{l}\text { Authorizes protective action recommendation to } \\
\text { off-post officials. }\end{array}$ \\
Staff Duty Officer/NCO & $\begin{array}{l}\text { Notifies off-post officials of chemical accident at } \\
\text { TEAD. }\end{array}$ \\
Director, TEAD Health Clinic & $\begin{array}{l}\text { Maintains liaison with local medical facilities } \\
\text { regarding diagnosis and treatment of chemical } \\
\text { agent casualties. }\end{array}$ \\
$\begin{array}{l}\text { Coordinates with the Toole County Sheriff's } \\
\text { Office and the Utah Highway Patrol for } \\
\text { directing traffic during civilian evacuation, } \\
\text { providing road blocks for access control and } \\
\text { highway clearing, and controlling access of trail } \\
\text { vehicles to evacuated areas. }\end{array}$ \\
$\begin{array}{l}\text { Maintains liaison with appropriate law } \\
\text { enforcement agencies. }\end{array}$ \\
$\begin{array}{l}\text { Prepares and disseminates approved news } \\
\text { releases to media. }\end{array}$ \\
Schedules follow-up briefings for the media and \\
public officials.
\end{tabular}

The Command Group and Personal Staff, under the command of the SRF Commander, direct and coordinate the overall operations of the SRF. A detailed description of the roles and responsibilities of the key personnel in this group is contained in Section 2.2.3.

The Special Staff Directorate, under the command of the Director for Special Staff, supports the SRF in specialized areas, in particular activities needing a significant interface with off-post civilian organizations and agencies. Key personnel groups in this unit include the Director for Special Staff, the Combat Pictorial Detachment (CPD), the Legal Officer, the Claims NCO, and the Restoration Planning Group. A description of the roles and responsibilities of these personnel is contained in Section 2.2.13. The roles and responsibilities of the Medical Officer and the Medical Service Corps Officer, also members of the Special Staff Directorate, are described in Section 2.2.8.

The Operations Directorate, under the command of the Director for Operations, coordinates and implements field and facility-based response activities from the functional areas in the EOC, the FCP, and the Joint Hazard Evaluation Center (JHEC). The responsibilities of key personnel assigned to the Operations Directorate are described under Section 2.2.10. 


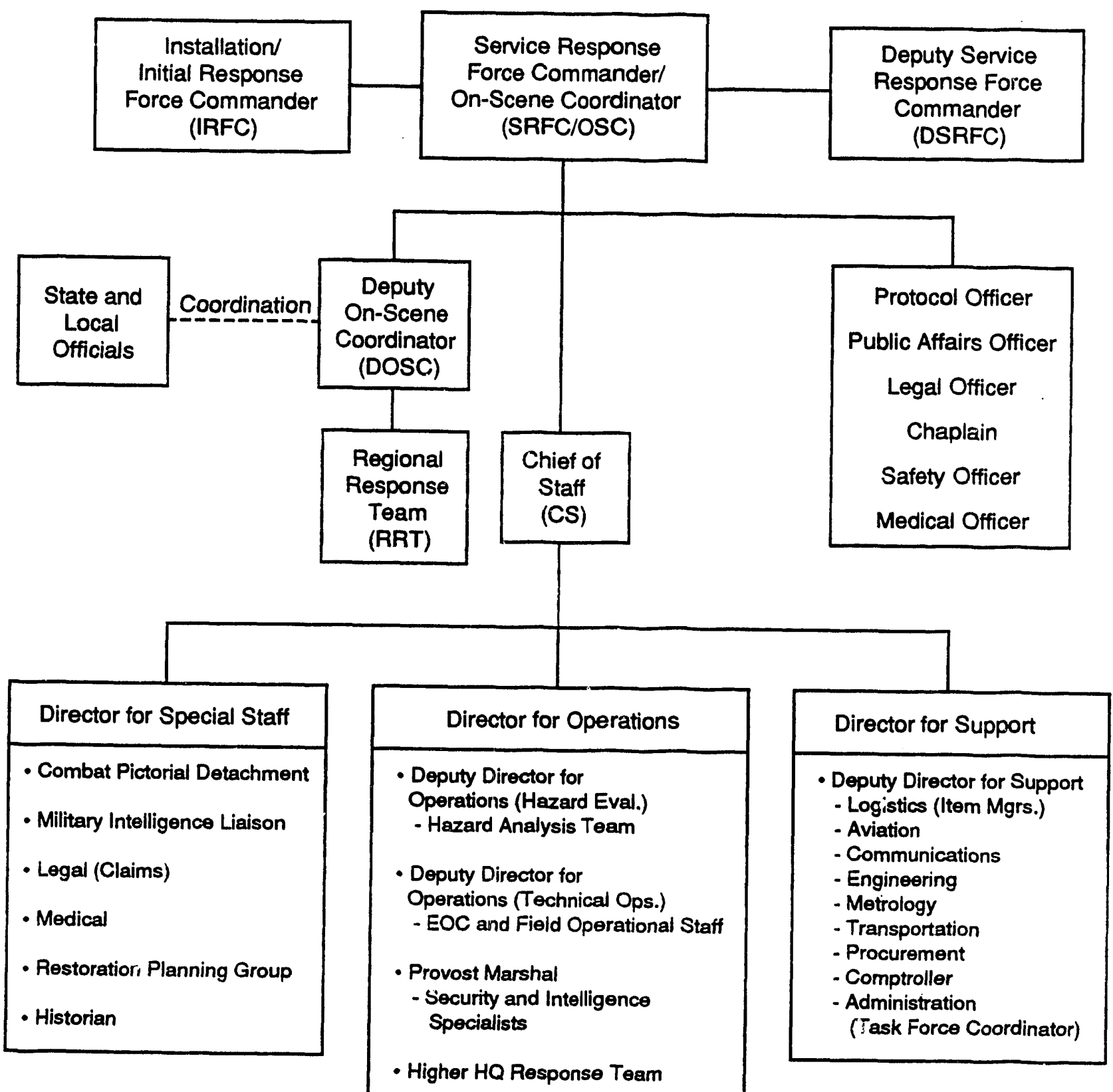

FIGURE 4 Simplified SRF Structure 
The Support Directorate, under the command of the Director for Support, provides all logistical and administrative support for the overall operation of the SRF during the accident recovery effort. Because the functions performed by this Directorate generally do not fit into the functional areas discussed in Sections 2.2.2 through 2.2.13, key Support Directorate personnel and their roles are described below.

The Director for Support is responsible for (1) ensuring the integration of responsibilities between SRF and IRF staff members, (2) guiding and assisting his or her staff as they complete their responsibilities, and (3) setting priorities for subordinate staff.

The Deputy Director for Support, as the primary military consultant in the Support Directorate, assists the Director in coordinating support activities. This military officer assumes the Director's responsibilities when the Director is absent, assists in preparing reports and briefings, and serves as the liaison between the Support Directorate and appropriate supporting activities. The Deputy Director also coordinates with DOD or other federal organizations to obtain additional support, when needed.

The Logistics Officer is the point of contact on all logistical support matters and is responsible for acquiring additional logistical support through coordination with DOD or other federal organizations.

Item Managers, under the direction of the Logistics Officer, maintain supplies inventory, identify sources and requisitioning protocols, and place requisitions for additional supplies. These individuals also track the turnaround time for recycled protective equipment.

The Engineer Officer is the primary point of contact on all matters related to the estimation, assessment, and correction of damage to real property at the accident site. All requirements for heavy equipment and construction equipment are routed to the Engineer Officer by Item Managers. This individual also determines the need for additional military engineering units.

The Aviation Officer coordinates all aviation requirements associated with the response to the chemical accident: (1) transporting the SRF Commander and Staff to the site, (2) determining and providing on-site aviation requirements to support overall operations, (3) notifying the Federal Aviation Administration ( $F \dot{A} A$ ) to restrict air space around the chemical accident site, and (4) coordinating the arrival of incoming response teams.

The Communications Officer is the primary point of contact for all communications matters at the chemical accident site. A more detailed description of this individual's responsibilities is contained in Section 2.2.4.

The Administrative Officer maintains a Response Team Manning Board, debriefs incoming response teams, and tracks outside resources brought duiring the response. Working through the Administrative Officer, the Task Force Coordinator (in some plans referred to as the Task Force Commander) is responsible for making initial assignments for incoming DOD response teams and supporting their efforts. Support provided includes making billeting and mess arrangements, securing adequate supplies of potable water, arranging for provision of electricity to temporary field facilities, and ensuring an adequate supply of latrines and shower facilities. 
The Transportation Officer coordinates and provides all aspects of transportation associated with response to the chemical accident site, including the travel of the SRF to and from the site (in coordination with the Aviation Officer) and the ground transport of personnel, equipment, and other materials at the site.

The Procurement Officer serves as the chief purchasing and contracting representative and administers all contracts issued in support of the SRF. This individual also arranges for the inspection of materials and services prior to acceptance to ensure contract compliance.

The Comptroller, in conjunction with the installation comptroller, establishes a system to identify costs associated with the response to the chemical accident. The Comptroller also estimates the potential funding required to support the response and may request emergency authority to commit resources to meet emergency requirements. Finally, this individual coordinates with outside federal agencies to determine the availability of additional emergency funding.

\subsubsection{Response Capabilities}

By definition, the SRF is capable of responding to all Army chemical accidents and of gaining control of chemical accident operations. SRF capabilities include (1) securing the chemical accident area, (2) assessing the damage caused by a cherrical accident, (3) assuring the medical treatment and evacuation of affected personnel, (4) determining and acquiring additional needed resources, and (5) stabilizing the situation prior to returning management of the accident back to the IRF Commander for implementation of site restoration activities in accordance with appropriate Army and regulatory directives.

\subsubsection{Direction and Control}

This section identifies and describes the roles of key personnel within the SRF Command Group.

\subsubsection{SRF Commander}

When present, the SRF Commander is the senior military official present at the site of a chemical accident; this officer represents DOD and DA and has operational control of all military forces and operations at the location. The SRF Commander has the authority to commit any Army materiel, equipment, or manpower deemed necessary to contain the chemical accident. In his or her role as the senior DOD representative at the accident location, the SRF Commander has direct access to the highest levels of DOD and DA.

The SRF Commander reports directly to the DA Deputy Chief of Staff for Operations (DCSOPS) at the AOC in the Pentagon, Washington, D.C. Through the AOC, the SRF Commander can request support from Headquarters DA, the U.S. Army Forces Command (FORSCOM), the U.S. Army Training and Doctrine Command (TRADOC), the U.S. Army Information Systems Command (USAISC), and the U.S. Army Health Services Command (HSC). Forces provided by TRADOC, USAISC, and HSC, as well as those committed under a 
Memorandum of Agreement (MOA) between AMC and FORSCOM, are under the operational control of the SRF Commander.

Once the SRF Commander has arrived and assumed command ${ }^{\prime}$ the IRF is integrated into the SRF. At the direction of the SRF Commander, the SRF Commander's Staff (or SRFCS) assumes operational control of the chemical accident and the various forces deployed to the chemical accident site. The SRF Commander also assumes the IRF Commander's role as the OSC to coordinate all federal response activities. (Because of the SRF Commander's dual role, his or her position is sometimes referred to as the SRFC/OSC.)

The SRF Commander is responsible for contacting the major subordinate command selected by Headquarters AMC to coordinite the selection of supporting staff, establishing communications with the $A O C$, and reporting immediately to the chemical accident site. After arriving at the chemical accident site, the SRF Commander is responsible for (1) determining the chemical accident status by interacting with the IRF Commander, (2) ensuring integ: ition of the IRF into the SRF, (3) providing guidance and assistance to SRF Stari, and (4) as the OSC, overseeing and coordinating the entire federal response effort, both on and off post.

After briefing the SRF Commander and transferring control to the SRF, the IRF Commander serves as an advisor on the SRF Staff. Other responsibilities include (1) overseeing those installation operations that continue normally, (2) assisting the SRF Commander in establishing relations with off-post state and local governmental and civilian groups and organizations, (3) as appropriate, attending news conferences and briefings with the SRF Commander, (4) notifying the next-of-kin of Army military and civilian casualties, and (5) ensuring the restoration of the accident site in accordance with applicable Army regulations and other regulatory directives.

\subsubsection{Other SRF Officers}

The Deputy OSC (or DOSC) reports directly to the SRF Comrnander and, as the principal deputy to the OSC, is also responsible for coordinating and directing the federal response operations in cooperation with state and local officials, other rederal agencies, and appropriate private organizations at the Off-Post Command Post (OPCP). Upon receipt of a report of a discharge, the Deputy OSC takes immediate actions to classify the size of the release, determine the appropriate course of action, and determine whether additional Army, state, or other assistance is needed. The Deputy OSC also assists the SRF Commander in notifying the RRT through the National Response Center.

The Deputy SRF Commander (or DSRFC) is responsible for establishing the command post from which the SRF Command Group will operate. Th. Deputy SRF Commander is also responsible for coordinating the implemertation of the restoration plan. In the absence of the SRF Commander, the Deputy SRF Commander assumes command of the SRF.

The SRF Commander's Public Affairs Officer (or SRFC PAO) serves as a personal advisor to the SRF Commander and assumes control of public affairs activities (see Section 2.2.12).

The Chaplain is designated by the AMC Staff Chaplain's Office and serves as the AMC Chaplain Crisis Response Team Leader. This individual is the moral, ethical, and spiritual 
advisor to the OSC (either the IRF Commander or the SRF Commander). In this capacity, the Chaplain (1) ensures that pastoral care, emotional support, and counseling are provided to those persons needing such services; (2) assesses the need for additional Chaplain support personnel; and (3) coordinates with local civilian clergies to meet special needs.

Should the SRF be so configured, the Chief of Staff (or CS) coordinates operations for the SRF by controlling actions for the Directors of Operations, Special Staff, and Support. In this capacity, the SRF Chief of Staff (1) coordinates with the Director for Special Staff to maintain knowledge of current public affairs activities, (2) reviews all SRF Staff reports prior to approval by the SRF Commander, (3) provides and oversees the Protocol Officer, (4) oversees the Task Force Commander, (5) explains the SRF organization to arriving agencies and units, and (6) responds to irate calls, e.g., from elected representatives or government officials. If the assigned SRF Commander's Staff does not include a Chief of Staff (this position is optional), these responsibilities will be assigned to the Deputy SRF Commander.

The Protocol Officer is responsible for coordinating the access, escort, and transportation of all high-ranking military and civilian personnel arriving at the installation. The Protocol Officer provides these services for personnel from all branches of the DOD, members of Congress, senior federal government officials, and state and local officials.

\subsubsection{Communications}

The radio networks in place at TEAD will serve as the primary means of communicatior: for the SRF (Table 1). The installation's telephone system will serve as the secondary communications system. If required, an additional radio system (AN/VRC-46/67) will be installed to communicate with helicopters and the Augmentation Force. Communicators will use current Communications-Electronics Operating Instructions. To the extent available and needed, secure communications between Headquarters DA and the accident site will be provided by the SRF.

As the primary point of coritact for all communications matters at the chemical accident site, the Communications Officer maintains an up-to-date inventory of communications assets at each installation and ensures that communications are available to link the SRF Commander with the FCP, the accident site, higher headquarters, and other assistance agencies.

\subsubsection{Hazard Assessment}

Initial hazard assessment is the responsibility of the IRF. Once the SRF is in place, responsibility for hazard assessment will be assumed by the Deputy Director for Operations (Hazard Evaluation), who oversees the activities of the Hazard Analysis Officer and the JHEC. The Hazard Analysis Officer analyzes data from low-level monitoring of air, water, and soil samples and provides results to hazard assessment groups.

The JHEC manages the collection of monitoring data, develops hazard projections and wind shift plots, maintains the initial hazard plot, and directs the downwind monitoring teams. Technical representatives from off-post organizations or agencies, including the U.S. Environmental Protection Agency (EPA) and state and local governments, will participate 
in the JHEC activities. Data collected and analyzed by the JHEC are made available to the Restoration Planning Group for development of the restoration plan.

The Environmental Officer, under the command of the Director for Special Staff, is responsible for assessing the extent of contamination and preparing an estimate of the impact of the contamination on public facilities. The Environmental Officer is also responsible for ensuring that restoration actions comply with appropriate standards and for notifying the EPA in the event of a chemical agent release.

\subsubsection{Alert and Notification}

The SRF is activated by a directive, from either Headquarters AMC or Headquarters DA, designating the SRF Commander and authorizing the mobilization of the SRF. The two headquarters are informed of the chemical accident by the IRF Commander.

Because of the length of time required to mobilize the SRF, it is highly probable that alert and notification of on-post installation personnel and off-post civilian populations will have been completed by the time the SRF is in place. Specific responsibility for alert and notification of potentially affected populations is the joint responsibility of TEAD (on-post populations) and off-post authorities (off-post populations).

\subsubsection{Protective Actions}

The IRF Commander is initially responsible for the development of protective action recommendations (PARs) for both on-post and off-post areas. PARs are conveyed to off-post authorities who then must decide whether to implement them. As described in Section 2.1.6, under extreme conditions it may be necessary for TEAD to alert the public directly. During the transition from the IRF to the SRF, the SRF Commander is responsible for ensuring that the downwind hazard to the local civilian population has been evaluated. The Deputy OSC will assist the SRF Commander in notifying off-post officials of operations as conditions warrant.

Since a situation severe enough to warrant mobilization of the SRF would also warrant the development and issuance of PARs (by the IRF Commander), the SRF Commander would probably not develop and issue PARs. However, if a second chemical accident were to occur after the SRF was in place, the SRF Commander would need to issue PARs.

The Deputy Director for Operations (Hazard Evaluation) coordinates with the Deputy Director for Operations (Technical Operations) to assist in the evacuation and eventual reoccupation of contaminated areas within the confines of the installation. The Hazard Analysis Officer coordinates with the Deputy Director of Operations (Technical Operations) and provides field data, obtained from stationary monitors and field monitoring personnel, to the EOC Operations Officer for comparison with contamination predictions.

\subsubsection{Health and Medical Services}

The Medical Officer is the chief medical advisor to the SRF Commander and serves as the primary point of contact for all health and medical matters. Upon his or her arrival at the 
installation, this person contacts the installation medical officer (i.e., Health Clinic Director), or the nearest civilian medical facility that can support medical requirements, to determine the status of the medical response. The Medical Officer's principle duties include (1) determining the extent of current casualties, (2) projecting future casualties, and (3) overseeing other medical staff. The Medical Officer also provides technical advice to off-post medical personnel for diagnosing and treating chemical agent casualties.

The Medical Service Corps Officer coordinates activities of the installation medical services starf, including the clinic or hospital, and medical augmentation teams provided by the HSC. Should the need arise, this person reviews installation Memorandums of Agreement with local hospitals and determines which hospitals will accept chemical casualties and have the required facilities. and supplies for decontamination and treatment of casualties.

\subsubsection{Mass Care}

The AMC CSRFCERP does not address mass care. Information about mass care is contained in Sections 2.1.9 (TEAD), 3.1.9 (Tooele County), and 4.9 (state of Utah) of this guide.

\subsubsection{Field Operations/Emergency Worker Exposure Control}

Field operations are the direct responsibility of the Director for Operations, who is generally tasked with the management of functional areas in the EOC, FCP, and JHEC and all personnel assigned to those facilities. The responsibilities of key personnel assigned to the Operations Directorate are described below.

The Deputy Director for Operations (Hazard Evaluation) is responsible for development of all technical appraisals relating to the actual and potential impact of a chemical accident, including preparing site contamination assessments, periodically updating downwind hazard data, and forwarding contamination assessments to the Restoration Planning Group. The Deputy Director works in concert with the Deputy Director for Operations (Technical Operations) to provide assistance in the evacuation and eventual reoccupation of contaminated areas within the installation.

The Hazard Analysis Officer is responsible for developing site contamination assessments and updating downwind hazard data. More information on this position is provided in Sections 3.1.5 and 7.

The Meteorological Hazard Specialist (HAZMET) reports to the Hazard Analysis Officer. Throughout CAIRA operations, this individual provides operational support and uses meteorological and hazard assessment models to provide guidance and advice on the safety of operations.

The Briefing Officer develops, schedules, and conducts overview briefings to describe the status of technical operations. These briefings are conducted periodically during shift operations and, as a handoff briefing, at the end of each operations shift. These briefings ensure that incoming personnel are aware of the technical status of the response before they assume their assigned positions. 
The EOC Operations Officer, who reports directly to the Deputy for Operations (Technical Operations), oversees operations within the EOC. He or she is responsible for ensuring that all EOC positions are staffed and provides assistance to all personnel assigned to the EOC. The Operations Officer's principal duty is to coordinate the preparation and submission of supplemental Chemical Event Reports, which capture significant information for reporting to the AOC at Headquarters DA. These reports contain information on the status of the response to the chemical accident, including a statement of what has happened since the previous report, the current emergency classification level, a description of any property damage or casualties, an indication of whether any off-post medicai services or facilities are required, and the SRF Commander's assessment of the situation. Completed reports are submitted to the Director for Operations for review prior to final approval ard signature by the SRF Command Group.

The Higher Headquarters Response Team is responsible for handling inquiries from higher headquarters, for example AMC, DA, and the Joint Chiets of Staff. The response team can cross Directorate chain-of-command boundaries to quickly respond to inquiries.

The Deputy Director for Operations (Technical Operations) directs all field operations from the EOC and maintains direct communications with personnel at the FCP. As needed, the Director participates in the development of the site restoration plan with the Restoration Planning Group. The Deputy Director coordinates with the Deputy Director for Operations (Hazard Evaluation) to provide assistance in the evacuation and eventual reoccupation of contaminated areas within the installation.

The FCP Officer oversees all field operations and activities at the accident site, including the operations and activities of the following support teams:

- EOD Unit

- Low-Level Monitoring Team

- Decontamination Team

- Survey/Detection Teams

- Toxic Material Handlers

- Contamination Control Station

- Fire Department

- Search and Rescue Team

- Hotline Team

The Surety Officer serves as an advisor to the Deputy Director for Operations (Technical Operations) on the status and coordination of the various surety operations taking place at the accident site. The Surety Officer's primary duty is to attempt to account for the munitions or chemical agent involved in the chemical accident, including the identification of the type and quantity of munitions or chemicals involved, as well as quantities destroyed or missing. 
As the SRF point of contact for all safety actions, the Safety Officer is directly responsible for completing the safety portion of the Chemical Event Report and monitoring the adequacy of decontamination procedures and efforts.

The EOD Officer is responsible for coordinating the field operations involving EOD personnel, including initial entry to the chemical accident site. The initial entry is conducted to save lives and to collect information for assessment of the accident situation. EOD personnel, directea by the EOD Officer, are responsible for identifying, detecting, and containing or eliminating any explosive or toxic hazard associated with chemical weapons or agents. The EOD Officer also assists installation field personnel during personnel decontamination.

As the resident expert in personal protection, the Chemical Officer assists field teams in becoming familiar with their protective masks and other protective equipment. His or her duties include making recommendations regarding the type of protective equipment needed by response force field teams and conducting inspections and tests of protective equipment and clothing to determine whether it is operational.

The Technical Escort Officer oversees the activities of the Technical Escort Unit (TEU), which provides for the proper conveyance and routine disposal of hazardous explosive material. The TEU also provides assistance to field personnel at Personnel Decontamination Stations (near the Hotline).

The Quality Assurance (Surveillance) Officer, in conjunction with installation surveillance and inventory personnel, identifies the type, quantity, and quality of munitions involved in the accident: This individual also serves as the interface between the Deputy Director for Operations (Technical Operations) and the Hazard Analysis Officer(s) and, in this capacity, provides advice on chemical munitions hazards.

The Provost Marshal is exclusively responsible for the security of the installation confines, including the chemical accident site. A more detailed description of his or her responsibilities is included in Section 2.2.11.

The Security and Intelligence Officer is responsible for a number of functions to support the Provost Marshal: (1) providing information and guidance on operational security; (2) ensuring that all documents are given an Operational Security review; (3) providing security support such as badging and equipment; (4) establishing security requirements for sensitive materials, equipment, or areas; and (5) coordinating threat information and intelligence with offpost law enforcement agencies.

\subsubsection{Traffic and Access Control}

Initial control of traffic and access to the chemical accident site is the responsibility of the installation security force. Once the SRF has been mobilized and is in place, the Provost Marshal, who reports directly to the Director for Operations, is responsible for controlling personnel and materiel at the accident site. This responsibility includes controlling vehicular and personnel access to the general areas within the installation, as well as restricting access to specific areas. Information about specific boundaries of restricted areas, including the accident site, other restricted areas, and restricted roadways, will be provided to the SRF Commander's $\mathrm{PAO}$ and JIC PAO in the form of a diagram. 
If necessitated by emergency circumstances, the ranking DOD official at the accident site may establish an NDA. Establishing an NDA temporarily transfers control of nonfederal lands to the DOD for the purpose of safeguarding classified defense information and protecting DOD equipment.

Should non-DOD assistance be required in securing off-post areas, the Provost Marshal will obtain such assistance from state and local law enforcement organizations. Any such requests for additional off-post assistance will be coordinated through the Deputy OSC.

\subsubsection{Public Information}

Following a determination by the IRF Commander that SRF assistance is needed, the installation PAO notifies the Office of the Secretary of Defense (Public Affairs) [OASD(PA)] that an SRF has been requested. When directed by the OASD (PA), the installation PAO first notifies the DA public affairs chief and then notifies AMC Public Affairs (AMCPA). Once the required notifications are completed, the installation PAO begins preparing the JIC. The installation PAO defers all public affairs activities to the SRF Commander's PAO after his or her arrival.

The AMC CSRFCERP identifies two PAOs within the SRF. The SRF Commander's PAO is the SRF Commander's personal PAO and serves on the Personal Staff as an advisor to the SRF Commander on all public affairs matters. This PAO provides periodic updates to the SRF Commander on the activities at the JIC and coordinates, with the JIC PAO, the scheduling and content of all press briefings involving the SRF Commander.

The JIC PAO, who reports directly to the SRF Commander's PAO, is responsible for the actual operation of the JIC. The JIC PAO is to establish liaison with installation public affairs personnel and serve as the principal point of contact between the news media and CAIRA experts. Also, the JIC'PAO is responsible for the preparation and dissemination of SRF press releases related to the chemical accident and associated recovery efforts. Working through the Director for Special Staff, the JIC PAO will coordinate, as appropriate, news releases with all Directors, the Legal Officer, and the Security Officer. Draft releases are reviewed by the SRF Commander's PAO prior to forwarding them to the SRF Commander for release approval. In addition to developing and disseminating news releases, public affairs teams are also involved in analyzing public response to the accident in order to control rumors.

All SRF personnel, including medical, legal, and security forces, who are likely to have contact with civilian officials, the public, or the news media are explicitly instructed not to answer questions regarding the status of the chemical accident. They are instructed to defer all questions to the public affairs team at the JIC.

State and local public affairs personnel are not part of the SRF, but they participate in the JIC to coordinate information presented to the general public through the media. A Public Affairs Augmentee will be located at the OPCP to ensure that current response information is exchanged between the OPCP and JIC. 


\subsubsection{On-Post/Off-Post Interfaces}

This section describes the roles and responsibilities of Special Staff Directorate personnel who provide interfaces between the SRF and off-post civilian organizations and agencies.

The Director for Special Staff is responsible for oversight of the Special Staff Directorate. His or her specific responsibilities include (1) providing assistance to directorate members, (2) requesting support from other services through appropriate channels, and (3) requesting names of other services' observers from the AOC.

The Combat Pictorial Detachment provides, through its nine video and still photographers, a visual record of the chemical accident site and various response activities for analysis during operations and after the accident has terminated.

The Legal Officer is the legal advisor to the SRF Commander and, upon request, other federal officials. In this capacity, the Legal Officer evaluates the legal ramifications of the chemical accident. This individual also advises other members of the SRF about matters of security and the use of deadly force, the release of public information through the media, claims filed against the government for losses, and compliance with applicable environmental laws. The Legal Officer also coordinates and resolves legal issues with state and federal environmental regulatory authorities during site restoration efforts. Finally, this person establishes a liaison with state and local legal and law enforcement officials.

The Claims NCO processes claims by coordinating with FORSCOM augmentation claims teams. The claims operation, under the direction of the Legal Officer, is a critical interface between the SRF and off-post officials and civilians.

The Restoration Planning Group is comprised of the Restoration Planning Officer; the Chemical Research, Development and Engineering Center (CRDEC) Liaison Team; the Safety Officer; and the Environmental Officer. The roles and responsibilities of these personnel are described in Section 7.

The interfaces between SRF personnel and off-post officials and agencies are summarized in Table 3. 
TABLE 3 SRF/Off-Post Interfaces

SRF Position or Center

SRF Commander (SRFC/OSC)

Deputy OSC (DOSC)

IRF Commander (IRFC)

Chaplain

Protocol Officer

Joint Hazard Evaluation Center (JHEC)

Environmental Officer

Medical Officer

Medical Service Corps Officer
Interface Description

As the OSC, oversees and coordinates the entire federal response effort.

Coordinates and directs federal response operations in cooperation with state and local officials, other federal agencies, and appropriate private organizations at the OPCP.

Advises and assists the SRF Commander in establishing relations with off-post state and local groups (both governmental and civilian) and notifies the next-of-kin of civilian casualties.

Acts as liaison between the SRF and local community clergies for coordination of ministerial requirements.

Coordinates the access, escort, and transportation of all high-ranking military and civilian personnel, including members of Congress, senior federal government officials, and state and local officials.

Coordinates with off-post technical representatives during development of the monitoring plan and direction of field monitoring teams. Consults with these representatives on interpretation of technical data and clarification of area-unique information (such as topography and demographics).

Ensures notification of EPA in the event of a chemical agent release.

Contacts nearest civilian medical facility that can support medical requirements to determine the status of the medical response. Will provide technical advice to off-post medical personnel for diagnosing and treating chemical agent casualties.

As required, will contact local area hospitals to determine if they can accept chemical casualties and have the required facilities and supplies (particularly the required antidotes) for decontamination and treatment of casualties. 
TABLE 3 (Cont'd)

SRF Position or Center

Interface Description

Security and Intelligence Officer

Coordinates threat information and intelligence with civilian law enforcement agencies from all levels of government.

Provost Marshal

Obtains assistance from state and local law enforcement agencies for securing off-post areas.

Joint Information Center (JIC)

State and local p:rblic officials plan to participate in news briefings and JIC activities. A mutual aid agreement, covering the coordination of emergency public information, is under development and should be in place by June 1991.

JIC PAO

Public Affairs Augmentee

Deputy Director of Support

Serves as principal point of contact between the news media and CAIRA experts.

Facilitates the timely exchange of current response information between officials at the OPCP and JIC.

Coordinates with DOD and other federal organizations to obtain additional support.

Logistics Officer

Acquires additional logistical support through coordination with DOD or other federal organizations.

Aviation Officer

Notifies the FAA to restrict air space around the chemical accident site.

Comptroller

Coordinates with outside federal agencies to determine the availability of additional emergency funding.

Legal Officer

Upon request, provides legal advice to nonDOD federal officials. Coordinates and resolves legal issues with state and federal environmental regulatory authorities during site restoration efforts. Establishes a liaison with state and local legal and law enforcement officials. 


\section{LOCAL RESPONSE}

The purpose of this section is to describe the Tooele County plans and procedures currently in place for responding to an accident at TEAD. Discussion of the Tooele County response was derived from review of the Tooele County Emergency Operations Plan (EOP). The responsibilities of and expectations for support from municipalities in Tooele County and from nearby Salt Lake and Utah counties are also discussed.

\subsection{CHEMICAL ACCIDENT RESPONSE BY TOOELE COUNTY}

\subsubsection{General Concept}

The initial civilian response to an accident at TEAD will be at the local level, with the state alerted as needed to supplement the local response. Upon notification of a chemical accident at TEAD, the Tooele County Board of Commissioners and officials of local jurisdictions will form a Unified Command Group to direct and control emergency operations from the Tooele County EOC, which is in the basement of the Tooele City Hall at 47 South Main Street. (In case of directed emergency evacuation of the primary Tooele County EOC, an alternate EOC will be established in the Salt Lake County EOC, 440 South 300 East, Salt Lake City.) The Tooele County EOC will be the central point of communications and coordination of all off-post county emergency response actions to a chemical accident at TEAD, except for public information, which will be coordinated at the JIC.

\subsubsection{Response Capabilities}

Tooele County is prepared to provide communications, some hazard assessment, off-site alert and notification (including route alerting), implementation of protective actions, fire fighting and rescue activities, medical care, security and access control, and mass care. These capabilities are summarized in the following sections.

\subsubsection{Direction and Control}

Upon receipt of a warning message from TEAD (via the Statewide Law Enforcement Radio Band or the Utah State CEM Repeater Network), the Director of the Tooele County CEM activates the Tooele County EOC, calling in his or her staff, including representatives from the County Sheriff's Department, municipal fire and police departments, County Development Services, the County Clerk and the Auditor/Treasurer, the County Health Department, and the U.S. Department of Agriculture (USDA) Emergency Board. These representatives will form the County Unified Command Group that will direct operations at the local level for the duration of the incident. The mayors of Rush Valley, Ophir, Tooele, Grantsville, Stockton, and Vernon also are notified via radio pager. 
The following Tooele County positions are not currently staffed, but are to be appointed:

- Public Information Coordinator

- Reception and Care Coordinator

- Resources Coordinator

- Transportation Coordinator

\subsubsection{Communications}

Tooele County is responsible for controlling, directing, and providing communications once notification of an incident at TEAD has been received. All messages about an accident at TEAD are given automatic priority. The communications systems to be used are state systems or commercial systems, not exclusively county systems. systems:

Tooele County emergency operations will rely on the following communications

- Statewide Law Enforcement Radio Band

- Utah State CEM Repeater Network

- Commercial Telephone

- Radio Amateur Communications Emergency System (RACES)

Most of the Tooele County EOC staff will be contacted by commercial telephone. Backup power is in place at the Tooele County EOC to ensure that radic communications ard other systems can be operated during a power failure.

\subsubsection{Hazard Assessment}

Initial assessment of the accident will be done on-post by TEAD, and off-post organizations will depend on the Army to provide an ongoing assessment throughout the emergency. Analysis of longer-'erm off-post effects also will be done by the Army, assisted by the state, the USDA, and others as needed, and observed and verified by the County Health Department. This activity is to be done on an ad hoc basis during a response. The Army expects to coordinate with off-post officials during this process; a new system to provide the county with the ability to project the plume and share other technical information is being developed.

\subsubsection{Alert and Notification}

TEAD is responsible for activating the alert and notification system. Figure 3 depicts the order of notification by organization. 
A Non-Surety Emergency will be declared when events are likely to occur or have occurred that pose no chemical surety hazard but may be perceived as a chemical surety emergency or that may be of general public interest. The installation may notify off-post organizations so that they will be informed, but no increased state of readiness will be needed at this level. ${ }^{*}$ For a Limited Area Emergency (CA/I Phase I), TEAD may notify the Tooele County Sheriff's Office, which will notify other off-post governments and organizations as appropriate (see Fl zure 3). For a Post-Only Emergency (CA/I Phase II), the Tooele County Sheriff's Office will notify the Utah State Highway Patrol; the Utah County Sheriff; the Salt Lake County Warning Center; the Utah CEM; mayors and fire and police chiefs of cities within the IRZ; and, if necessary, the Union Pacific Railroad Dispatcher and the Barrick Mercur Gold Mine. All health care facilities are notified at this stage by the Tooele County Health/Medical Coordinator, who will be notified by the Utah CEM. The Tooele County EOC will be partially activated at this level. Once the Tooele County EOC is operational, the Tooele County CEM Director will establish the JIC in the Tooele County Courthouse. The JIC will be staffed by public information representatives from affected counties, TEAD, and the state, as appropriate. For a Community Emergency (CA/I Phase III), the Tooele County EOC will be fully activated, as will the State EOC, and, through the JIC, the public will be informed via the EBS.

Some minor differences exist between the TEAD CA/I Phases and the Tooele County ECLs. The Tooele County EOP refers to Community Emergency (Phase III) as an Off-Post Consequences ECL (for consistency, this guide uses the TEAD terminology). In addition, the Tooele County EOP states that off-post positions may be notified at CA/I Phase I and will be notified at Phase II, while the TEAD-DCP states that no notification is necessary for Phase I and that notification at Phase II is at the discretion of the IRF Commander. The plans are in agreement on the notification requirements for Phase III.

Currently, public warning and notification is to be accomplished by route alerting performed by the Sheriff's Office and local fire department personnel. The warning and notification process will be initiated when the Unified Command Group requests that the siren in Stockton be sounded using a special alerting modulation consisting of a steady siren sound for 3-5 minutes, which will be repeated twice after a 1-minute pause between each activation This will alert the fire fighters of the Stockton and Rush Valley Fire Districts, who will assist Tooele County Sheriff's personnel to conduct direct route alerting of all unincorporated or isolated areas within the IRZ. Additional assistance will be provided by local and state law enforcement personnel, as necessary. Finally, the Sheriff's "Jeep Patrol," a volunteer search and rescue squad, may assist if necessary. Personnel assigned will follow the routes listed in their department's implementing procedures.

If schools are in session, the Tooele County Dispatch Center will directly notify the School Superintendent, who in turn will notify school principals and the American Red Cross (ARC). Special populations, such as the hearing impaired, who require special notification are listed in the confidential file in the Tooele County EOC. They will be alerted in a house-to-house manner with neighbor and local assistance. However, it is unclear how the route alerting personnel will be given information about the hearing impaired and others with special needs.

\footnotetext{
*Since this ECL is not currently in the TEAD-DCP or Tooele County EOP, it may not be used during SRFX-91.
} 
After being alerted, the public will be given information and instructions about what actions to take (i.e., sheltering or evacuation) via EBS. Mobile patrols will occupy any preassigned Access Control Points and remain there until released by the Tooele County Unified Command Group. No one will be allowed to reenter a restricted evacuation zone until the Unified Command Group authorizes reentry.

\subsubsection{Protective Actions}

Recommendations for protective actions are to be made by the OSC. The Tooele County Unified Command Group makes the final decision on whether or not to evacuate the off-post population. However, a decision to implement evacuation and/or sheltering may be needed in as little as 3-5 minutes and it is unlikely that the Unified Command Group could be notified and assembled to consider the recommendation in this time frame. Should the Tooele County Sheriff's Department receive a recommendation to evacuate or shelter citizens immediately, it is unclear how a decision on the recommendation could be made in time to implement evacuation.

The County Sheriff and the Utah Highway Patrol will coordinate to establish traffic and access control for orderly evacuation once it is decided to evacuate. The Tooele County EOP provides a list of traffic control points (Attachment 1 to Appendix 1 to Annex $C$, Law Enforcement). The public is alerted as described above, and information about procedures and routes to take will be disseminated over the EBS using prescripted messages. These messages instruct those residents without a means of transportation to contact the Tooele County EOC.

\subsubsection{Health and Medical Services}

Tooele area Emergency Medical Services (EMS) will transport injured personnel and members of the public to the four area hospitals that have agreed to accept and treat cheinical agent casualties:

- Tooele Valley Hospital, Tooele

- Holy Cross Hospital, Salt Lake City

- University of Utah Medical Center, Salt Lake City

- $\quad$ LDS Hospital, Salt Lake City

The Tooele County EOP notes that personnel at these hospitals need special assistance to treat large numbers of patients contaminated by the agents stored at TEAD. The EOP assumes that the Army "will provide appropriate training and specialized assistance to local communities," including further training of hospital personnel (Appendix 1 to Annex E). Some hospital personnel have attended a course at the Centers for Disease Control (CDC) in Atlanta on chemical medical intervention. 
The EOP also ass imes that the Army will provide antidote supplies (atropine and 2PAM chloride) for treatment of chemical casualties. Currently, local hospitals do stock atropine, although not in very large quantities, but they do not have 2-PAM chloride. If additional quantities of atropine or any 2-PAM chloride were needed, Tooele County would request these supplies through the Installation Commander or SRF Commander. During the early stages of a response to an accident at TEAD, Army medical personnel are likely to be unavailable to assist in the treatment of casualties off post.

The County Health Coordinator notifies host health care facilities to make preparations to rereive evacuating pasients and chemical agent casualties, as appropriate. According to the EOP, the two primary host hospitals, Pioneer Valley and St. Mark's, have the capability of decontamination and tre $c_{-i}$ ment of chemical agent casualties, as do the other area hospitals listed above.

Additional ambulances that may be needed by Toofle County for medical evacuation may be obtained through coordination with the Utah Department of Heaith, Bureau of Emergency Medical Services. A Governor's declaration of a "State of Emergency," under the Disaster Response and Recovery Act (see Appendix A), would be necessary to ersure that ambulances would be available when reeded. Typically, the State of Emergency declaration would be preceded by a declaration of a Local Emergency by the chief elected official in Tooele County (President of the Board of County Commissioners).

\subsubsection{Mass Care}

Should evacuation of residents be ne'cessary, arrangements for sheltering, feeding, and otherwise caring for these evacuees are provided by host counties. The ARC has the primary responsibility for mass care, with shelter provided by the school districts in area schools. The host facilities include:

- Cyprus High C $_{\text {chool, Magna }}$

- Brockbank Jr. High School, Magna

- Magna Elementary School, Magna

- Webster Elementary School, Magna

- Pleasant Green Elementary School, Magna

Evacuee reception will also take place at:

- Lehi High School, Lehi

- Cyprus High School, Magna

- Tintic High School, Eureka

- Dugway High School, Dugway 
The planning assumption is that $25 \%$ of evacuees $(5,100$ people) would need shelter. Host facilities can accommodate a total of 6,200 people. Activities at the mass care shelters include registration of evacuees, medical screening, identification of special needs (i.e., medical or dietary), and dissemination of information to evacuees. Special needs are reported to the Tooele County EOC for resolution by the ARC liaison representative in the EOC.

\subsubsection{Field Operations/Emergency Worker Exposure Control}

As noted in Section 3.1.5, field operations involving sampling and measuring of potential contamination will be done by Army personnel trained and equipped to perform this task. The EOP calls for the County Health Department to assist with this work. The state has indicated that, to comply with the Occupational Safety and Health Act, it does not intend to send field monitoring teams into potentially contaminated areas.

Protection for other types of emergency workers, such as police and fire fighters, is available in limited quantities at this time. TEAD has provided protective masks only to the Tooele County Sheriff's Office and Utah Highway Patrol Troopers assigned to the Tooele area. If additional personnel are required to provide traffic and access control, it is unclear how or when they would receive protective masks. No other agent-specific protective clothing or equipment has been or is expected to be distributed. Evacuation of all persons from the affected area is the planned protective action for controlling exposure. However, the limited amount of protective equipment for emergency response personnel makes them very vulnerable. For example, direct route alerting of the population (critical while the area remains without sirens) may be impossible to accomplish safely and effectively without protective gear.

\subsubsection{Traffic and Access Control}

As noted in Section 3.1.7, traffic and access control will be provided the by Sheriff's Office and the Utah Highway Patrol. (Traffic and Access Control Points are listed in Attachment 1 to Appendix 1 to Annex C, Law Enforcement.) They will also secure the evacuated area(s).

\subsubsection{Public Information}

The media are to be briefed at the JIC (located at the TEAD North Area), which will be responsible for disseminating information about operations at the installation. A Memorandum of Agreement between the Army and Tooele County has been completed. Other agencies represented at the JIC will include the Utah CEM, Utah County, Salt Lake County, and others as needed.

All emergency public information will be approved by the Tooele County Unified Command Group and coordinated with and issued from the JIC. Attachment 5 to the Tooele County EOP contains a listing of the EBS radio and television resources. The EOP contains prescripted EBS messages. 


\subsubsection{On-Post/Off-Post Interfaces}

Table 4 describes the Tooele County organizations that interact with TEAD and are integral to the off-post local response.

\subsection{SUPPORT BY SALT LAKE COUNTY}

Salt Lake County provides backup support to TEAD and Tooele County for a variety of resources and assistance. For example, if Tooele County needs additional buses for evacuating residents, Salt Lake County would provide them, as well as fire fighting and police services. Ambulances and EMS will also be available for casualties both on and off post. Treatment and decontamination are available at LDS Hospital, Holy Cross Hospital, and University Hospital, also in Salt Lake City. Reception and mass care for a total of 5,000 evacuees are to be provided at the Cyprus High School, Brockbank Jr. High School, Magna Elementary School, Webster Elementary School, and Pleasant Green Elementary School, which are all in Salt Lake County.

In addition, Salt Lake County, through a Memorandum of Understanding with TEAD, has agreed to provide ambulance services to the installation for the evacuation of casualties to off-post medical facilities.

Emergency activities are coordinated by the Emergency Services Section of the Salt Lake County Fire Department from the Salt Lake County EOC in the main County Fire Department building and are supervised by the Director of Emergency Services. Initial notification would be received by the Valley Communication Center in Murray, which would forwara the information to the EOC in Salt Lake City. The Valley Center would receive and coordinate all requests from Tooele County for resources. The primary means of communication is by commercial telephone; however, new microwave radio equipment is expected to be in place by June 1991. This equipment will link TEAD, Tooele County, Salt Lake County, and Utah County.

\subsection{SUPPORT BY UTAH COUNTY}

Like Salt Lake County, Utah County will provide backup resources to Tooele County, primarily traffic control and mass care within Utah County. Decision-making representatives and elected officials will operate as a Unified Command Group at the Utah County EOC, 1776 South Buckley Lane, Provo. The Utah County Unified Command Group will make decisions for protective actions based on recommendations from the OSC. Public notification will be by direct route alerting and EBS announcements. Traffic and access control and other evacuation activities will be carried out by the local law enforcement agencies. Communica ions will be by radio with certain predesignated frequencies dedicated to certain agencies for the duration of the incident. 
TABLE 4 On-Post/Tooele County Interfaces

\begin{tabular}{|c|c|}
\hline Tooele County Position or Organization & Interface Description \\
\hline Tooele County Sheriff's Office & $\begin{array}{l}\text { Receives initial off-post notification of a } \\
\text { chemical accident/incident. Notifies other } \\
\text { county groups and assists with initial off-post } \\
\text { response. }\end{array}$ \\
\hline $\begin{array}{l}\text { Tooele County EOC (Director, Tooele } \\
\text { County CEM) }\end{array}$ & $\begin{array}{l}\text { Receives initial notification and forms Unified } \\
\text { Command Group. Maintains contact with the } \\
\text { TEAD EOC during accident response as the } \\
\text { primary interface between Tooele County and } \\
\text { Army forces at the installation. }\end{array}$ \\
\hline Tooele County Unified Command Group & $\begin{array}{l}\text { Decides whether to implement protective action } \\
\text { recommendations received trom the OSC. }\end{array}$ \\
\hline Tooele County Health Department & $\begin{array}{l}\text { Participates in planning hazard assessment and } \\
\text { fielc monitoring activities and in determining } \\
\text { impact of accident on Tootie County. }\end{array}$ \\
\hline County Health/Medical Coordinator & Coordinates response of off-post hospitals. \\
\hline
\end{tabular}

The part of Utah County that is not in the Protective Action Zone (PAZ)* is expected to be a destination for evacuees. The Lehi High School in Lehi will both receive and shelter up to 700 people under the direction of the ARC. Although the Tintic High School in Eureka is listed in the Tooele County EOP as able to receive and shelter up to 200 people, it is not mentioned as a shelter in the Utah County CSDP Plan. Host health care facilities in Utah County include the American Fork Hospital and the Utah Valley Regional Medical Center. Decontamination is to be provided by the Lehi Fire Department, the American Fork Fire Department, the Provo City Haz/Mat team, and the Utah County Health Department. Ambulances are available from four providers as listed in the Utah County CSDP Plan.

\footnotetext{
*The PAZ is that area where public protective actions may be necessary in case of a chemical accident, but where the available warning and response time is such that most people could bo effectively evacuated.
} 


\section{RESPONSE AND SUPPORT BY THE STATE OF UTAH}

This section describes the response by the state of Utah to a chemical accident occurring at TEAD. Material in this section reflects information contained in the current State EOP, interim draft, March 11, 1991, and its appendix specific to the Chemical Stockpile Emergency Preparedness Program (CSEPP), interim draft, February 26, 1991.*

During the response to a chemical accident at TEAD, the state of Utah's primary goal is to support the response by Tooele County and host county organizations. With the exception of Utah Highway Patrol Troopers, it is not anticipated that state personnel would engage in firstresponse activities. The following sections characterize the types of support that the state of Utah will provide at the request of county officials.

\subsection{GENERAL CONCEPT}

The Utah CEM is established within the Department of Public Safety. It has prepared and maintains programs and plans to provide for prompt and effective response to and recovery from disasters; coordination of federal, state, and local emergency activities; coordination of state and local EOPs with emergency plans of the tederal government; and coordination of rapid and efficient communications in times of emergency.

Under Utah's Disaster Response and Recovery Act, the principal executive officer of Tooele County, the Chairman of the Board of County Commissioners, may issue a "Local Emergency" proclamation. This proclamation is official recognition that a disaster situation exists and is the legal basis for requesting and obtaining state or federal government disaster assistance. After the proclaination of a local emergency, if the Governor of Utah finds that a disaster has occurred, or that the occurrence or threat of a disaster is imminent in any area of the state, he or she may declare a "State of Emergency." During a State of Emergency, the governor is authorized and empowered to (1) recommend and advise the evacuation of all or part of the population from any stricken or threatened area within the state if necessary for the preservation of life; (2) recommend routes, modes of transportation, and destinations in connection with evacuation; (3) suspend or limit the sale, dispensing, or transportation of alcoholic beverages, explosives, and combustibles; and (4) control ingress and egress to and from a disaster area, control the movement of persons within the area, and recommend the occupancy or evacuation of premises in a disaster area. Finally, during a State of Emergency, the Governor is commander-in-chief of the military forces of the state.

\subsection{RESPONSE CAPABILITIES}

As described above, the state of Utah would not typically deploy personnel in firstresponse activities. An exception to this is when Utah Highway Patrol Troopers, in particular those who have received special hazardous material training, are called upon to provide support to local officials dealing with spills or releases. These personnel, working with Department of

\footnotetext{
*The standard operating procedures (SOPs) that will provide additional implementation information for the Stato EOP are under development and will not be available for SRFX-91.
} 
Health and local health officials, comprise the initial technical advisory team available to local decision makers during a response.

\subsection{DIRECTION AND CONTROL}

Within the Utah Department of Public Safety, Utah CEM coordinates state emergency support provided to local communities in Utah. Currently, the State EOC is located at 1543 Sunnyside Avenue, Salt Lake City. By June 1991, the State EOC will have been moved to the basement of the State Office Building located across from the Capitol Building in Salt Lake City.

Emergency operations at the State EOC are typically directed by the Director of the Utah CEM or a designee. During the initial stages of a response to an accident at TEAD, the Director provides regular briefings to the Commissioner of Public Safety. If it appears that the accident will involve protracted emergency operations, the Director may move to the Tooele County EOC, leaving a designated operations manager to direct the State EOC. Once at the Tooele County $E O C$, the Director would continue to direct and coordinate state operations.

Operations of other state agencies are typically directed from the State EOC by their agency's management personnel. The Department of Health, for example, deploys an Assistant Director or a designee and support staff to the State EOC. From that location, the Assistant Director directs the Health Department's response. Requests for support by local officials are coordinated with appropriate agency personnel by Utah CEM operations staff.

Other agencies and organizations that report to the State EOC may include among others, the Department of Agriculture, the Department of Natural Resources, the Department of Transportation, the State Fire Marshal, the Board of Education, the ARC, and the Utah National Guard.

\subsection{COMMUNICATIONS}

The state employs several means of communication during emergency operations. Commercial telephone lines linking the State EOC to other state agencies and local EOCs are the primary means of communication. Numerous statewide radio networks are also available as backups. The Utah CEM has a statewide emergency management radio network that provides backup communications between Utah CEM and both risk and host counties in the Tooele area (this system will be upgraded with the addition of a microwave system, covering all of the Tooele area, to be installed and operational by June 1991). The Statewide Law Enforcement Radio Band is available to communicate with various Utah Highway Patrol mobile units and area offices throughout the state, including the Tooele office. The Department of Health relies on two means of communications - cellular telephones and some portable radios - to communicate with its personnel in the field.

\subsection{HAZARD ASSESSMENT}

The response to a chemical agent accident at TEAD would be similar to that required for a hazardous material spill. The response would be a cooperative effort involving the 
Department of Health, the Utah Highway Patrol, local fire and police agencies, and county health personnel. The state can provide technical assistance for hazard assessment to Tooele County in the following areas:

- The Utah Highway Patrol has designatea several troopers for spill response. These troopers have received training in the response to and control of hazardous materials spills.

- Troopers from the Tooele office, who will be part of the Tooele County Unified Command Group, will provide assistance in the early phases of a response.

- Through its staff at the State EOC and those dispatched to the Tooele County EOC, the Department of Health will provide technical assistance in five areas:

- Hazardous material identification

- Potential health effects determination

- Spill containment

- Hazard mitigation

- Spill cleanup and disposal.

The Department of Health will provide support to local officials in each of the above areas, in concert with Army technical experts. Through this cooperative effort, the Department of Health will participate in developing monitoring and sampling plans, identifying areas to be sampled, interpreting field data, and developing specific actions on the basis of interpreted field data. Initially, technical data collected by the Army will be shared with off-post officials through the Deputy OSC (at the OPCP). As the accident response progresses, off-post technical experts will have the opportunity to provide input through the JHEC.

\subsection{ALERT AND NOTIFICATION}

The Utah CEM will receive notification of an accident at TEAD from the Tooele County Sheriff's Office. Under the TEAD-DCP and with the approval of the IRF Commander, the Tooele County Sheriff's Office is notified at CA/I Phase II or III. The Sheriff's Office then notifies the Tooele County CEM, which, in turn, notifies the Utah CEM (see Figure 3).

Once the Utah CEM has been notified by the Tooele County CEM, it notifies other state agencies. The Department of Health may also be notified of the accident directly by the Tooele County Health Department. Similarly, the Utah Highway Patrol may be notified by both the Utah CEM and its Tooele County office.

If necessary, the Utah CEM does have the capability to issue a statewide alert and provide emergency public information over the EBS. 


\subsection{PROTECTIVE ACTIONS}

The state's role in protective action decision-making occurs at the Tooele County EOC, where the liaison from the Utah Highway Patrol (Tooele office) participates as a member of the Unified Command Group. If evacuation is selected as the protective action, the Utah Highway Patrol will provide troopers to assist local law enforcement personnel in staffing traffic control points. Once an evacuation is completed, troopers will similarly participate in access control efforts.

Additional ambulances that may be needed by Tooele County to evacuate the mobility impaired may be obtained through coordination with the Utah Department of Health, Bureau of EIMS. The Bureau of EMS is the licensure authority for emergency medical personnel throughout the state and maintains records of available private and public resources. For counties with mutual aid agreements, the ambulances covered under such written agreements are coordinated directly through the assisting counties. Although such agreements are planned, none are currently in place. In the absence of mutual aid agreements, a Governor's declaration of a "State of Emergency" would make ambulances available to county agencies (see Appendix A).

\subsection{HEALTH AND MEDICAL SERVICES}

The Department of Health coordinates the provision of supplementary health/medical assistance that might be needed by local governments (municipalities or counties). This assistance typically consists of providing information or coordination in order for the local government to obtain additional personnel, facilities, or equipment to support medical service activities.

\subsection{MASS CARE}

Should sheltering/housing of evacuees become necessary, the Tooele County Health Department and the ARC, Salt Lake Area Chapter, will coordinate efforts. The Department of Health will designate the safest shelter outside the disaster area and will contact the ARC to open the shelter, typically a high school. ARC-trained disaster response personnel will staff the shelters. The Department of Health will also provide assistance in staffing these shelters with nursing personnel trained in the diagnosis and treatment of chemical agent exposure. In addition to managing the shelter, the ARC will feed evacuees and assess their needs. The ARC will also coordinate the identification, notification, and provision of additional health and medical resources needed to support the mass care shelters.

Other state agencies are prepared to provide additional resources should they be needed and requested. In most cases, these requests for assistance will come from the counties in the Tooele area and will be directed to the State EOC, which will forward requests to the appropriate state agency through the Utah CEM. 


\subsection{FIELD OPERATIONS/EMERGENCY WORKER EXPOSURE CONTROL}

Since the state of Utah does not have personal protective equipment for use in chemical agent environments, state field operations will be limited to support for an evacuation (if needed) from areas around TEAD and within the IRZ or PAZ. TEAD has provided gas masks to troopers assigned to the immediate area of TEAD.

The Utah Highway Patrol will provide support to local law enforcement agencies in traffic and access control and will provide more limited support for the first response. Due to Occupational Safety and Health Administration (OSHA) regulations, state and local personnel will not engage in field monitoring during the response phase of an accident at TEAD.

\subsection{TRAFFIC AND ACCESS CONTROL}

As described in Section 4.7, Utah Highway Patrol Troopers, through participation in the Law Enforcement Group at the Tooele County EOC, will assist local law enforcement agencies by staffing and maintaining traffic and access control points. If needed, additional troopers would be brought in from other areas around the state.

\subsection{PUBLIC INFORMATION}

In the early stages of a response, Utah's spokesperson would be the Director of the Utah CEM or a designee. The Director can issue statements to the press from the State EOC or the JIC located near the TEAD North Area. The JIC will permit the state to participate with Army representatives in unified press briefings. The Director will, through the Commissioner of Public Safety, provide periodic briefings to the Governor's Office.

\subsection{ON-POST/OFF-POST INTERFACES}

Table 5 lists the on-post/state interfaces that will coordinate the state of Utah's support for response to a chemical accident at TEAD. 
TABLE 5 On-Post/State of Utah Interfaces

State Position or Organization

Interface Description

State EOC

Establishes and maintains communications (telephone and radio) with TEAD.

Director of Utah CEM

May participate in unified press briefings at the JIC.

Department of Health personnel

Work with Army personnel to develop field monitoring plans and identify monitoring protocols.

Utah Highway Patrol Troopers

Support local law enforcement agencies in providing access and traffic control. 


\section{RESPONSE AND SUPPORT BY THE REGIONAL RESPONSE TEAM}

This section describes the plans and procedures currently in place for response to an accident in Region VIII by the Regional Response Team (RRT) as identified in the Regional Oil and Hazardous Substances Pollution Contingency Plan (RCP) for Region VIII (the states of Utah, Colorado, Montana, North Dakota, South Dakota, and Wyoming). While the RRT's general functions and capabilities are discussed, emphasis is placed on how the team would respond to an accident at TEAD.

\subsection{GENERAL CONCEPT}

The RRT is the regional mechanism for pre-response planning and preparedness activities for potential hazardous materials discharges. It is also responsible for coordination of assistance and advice to the OSC during an incident. The two principal components of the RRT are a "standing" team and an "incident-specific" team. The standing team consists of designated representatives from each participating federal agency, state government, and local government. The incident-specific team is formed at the time of an accident from the membership of the standing team, which includes representatives from the DOD, EPA, USDA, Federal Emergency Management Agency (FEMA), Department of Commerce (DOC), Department of Health and Human Services (DHHS), Department of Labor (DOL), Department of the Interior (DOI), Department of Transportation (DOT), Navajo Nation, and each state in the region. Also potentially involved are the CDC, National Park Service, Bureau of Reclamation, Department of Justice (DOJ), Department of State (DOS), and Nuclear Regulatory Commission.

The RRT is activated by request from any RRT member to the Chair or by request from the NRT. The RRT is activated when a contaminant discharge or release exceeds the response capabilities available to the OSC or when a discharge or release poses a substantial threat to public health, welfare, or the environment. A severe accident at TEAD could pose such a threat.

\subsection{RESPONSE CAPABILITIES}

The role of the incident-specific team depends on the type of accident. Various members of the standing team are called upon to provide the expertise needed to help contain and clean up the contaminant. When activated, RRT members may:

- Provide advice, as requested by the OSC;

- Advise the OSC on the duration and extent of federal response and recommend specific actions to respond to a discharge or release;

- Request other federal, state, or local government or private agencies to provide resources under their existing authorities either to help respond to the incident or to monitor the response;

- Recommend to the RRT Chair, if circumstances warrant, that a different OSC be designated; 
- Monitor and evaluate reports from the OSC; and

- Ensure continual communications.

The various member agencies would have different roles, responsibilities, resources, and types of assistance to offer the OSC during an incident at TEAD. They are outlined briefly below.

The EPA can provide technical expertise and resources to the OSC to assist with environmental protection and mitigation, including determination of environmental effects of discharges and environmental control techniques. The EPA has established Environmental Response Teams (ERTs) to provide expertise in biology, chemistry, hydrology, geology, and engineering. Additionally, the EPA can provide legal expertise on the interpretation of environmental statutes and can enter into contracts or cooperative agreements with the state to implement a response action.

FEMA can provide assistance to the lead agency to coordinate temporary or permanent relocation of residents, businesses, or facilities. FEMA can also provide communications support, if needed. If a Presidential Disaster Declaration is issued, FEMA coordinates all federal assistance activities.

The USDA can provide expertise in managing agricultural, forest, and wilderness areas and in selecting landfill disposal sites. The Soil Conservation Service (SCS) can help predict the effects of pollutants on soil and their movements over and through soil.

The DOC, through its National Weather Service (NWS), can provide climatic weather and hydrologic forecasts for land areas. The NWS also operates a network of 370 continuous broadcast radio stations that can be used to communicate information on life- or propertythreatening events directly to the general public and media. It also supports a satellite-based hard copy service that links the NWS to the media (including press wire services), state agencies, and local emergency and civil defense managers. In addition, the National Oceanic and Atmospheric Administration (NOAA), also within the DOC, maintains the Computer-Aided Management of Emergency Operations (CAMEO) programs and contingency plans for first responders.

The DHHS can provide advice concerning potential effects on public health that may result from a hazardous substance release. Physicians, nurses, public health advisors, and other personnel of the Public Health Service (PHS) may be called upon to assist in major incidents. The $C D C$ can be asked to provide emergency response consultation, epidemiology services, and toxicological experts; the CDC can do health studies when needed. The Public Health Service's Agency for Toxic Substances and Disease Registry (ATSDR) has a national 24-hour emergency response telephone number (FTS 236-0615 or commercial 404-639-0615) for advice and guidance concerning public health. The ATSDR hotline can be used by any federal, state, or local official to augment regional capabilities.

The DOL, through OSHA, can provide the OSC with advice and assistance regarding hazards to persons involved in the removal or control of hazardous substances spills or discharges and in the precautions necessary to prevent endangerment of their health and safety. 
The DOI can provide information about the lands and resources specifically under DOI jurisdiction, as well as offer technical expertise related to geology, hydrology, minerals, fish and wildlife, and cultural and recreational resources. In addition, the Bureau of Indian Affairs (BIA) can assist in coordinating activities affecting Indian lands.

The DOT can provide expertise pertaining to the packaging and highway transportation of hazardous materials and substances. The Nuclear Regulatory Commission and the Department of Energy (DOE) would probably not be involved with an accident at TEAD, as their missions are primarily directed towards dealing with radioactive materials. The DOJ can provide legal advice to deal with judicial questions arising from discharges, releases, and federal agency responses. The DOS would be involved if an international response were needed.

\subsection{DIRECTION AND CONTROL}

For meeting and planning purposes, the EPA and U.S. Coast Guard act as cochairs of the RRT. In the event of an incident inland, the EPA provides the predesignated OSC; the Coast Guard provides the OSC if waterways have been affected. However, if the discharge is from a DOD facility or vessel, then DOD provides a predesignated OSC who will be the Officer in Charge of the facility (for SRFX-91, the OSC will be the IRF Commander initially, and the SRF Commander once he or she has assumed command of the DOD response forces). The OSC will be responsible for directing and controlling all operations tor containment, notification, and cleanup at the site of the accident.

The RCP indicates that the primary link between the OSC and the RRT would be the RRT Chair, who would be a representative from EPA. According to the AMC CSRFCERP, the Deputy OSC would be the primary interface between the OSC and off-post officials. It is unclear how this arrangement will work with the RRT as, typically, the EPA Co-Chair would provide technical advice to both the OSC and off-post officials.

\subsection{COMMUNICATIONS}

No specialized communications systems are indicated for the exclusive use of the RRT. It is expected that the RRT will use whatever systems are available at the accident site.

\subsection{HAZARD ASSESSMENT}

Initial assessment of the accident is to be done by the first federal official on-site, the IRF Commander at TEAD. Analysis of longer-term, off-site effects would be done by the local authorities with assistance provided from the state and federal government as needed. 


\subsection{ALERT AND NOTIFICATION}

Any RRT or NRT member can activate the RRT by a request to the RRT Chair. If regional assistance were needed for a chemical accident at TEAD, the DOD would notify the EPA designee and request assistance. The three types of activation are:

- Standby -- Notice to some or all RRT members to be ready to respond (phone notification only).

- Partial -- Notice to selected members that their services are required and indicating what the service is to include (phone call with written verification).

- $\quad$ Full -- All RRT members are notified that their services are required and told what that service will be (phone call with written verification).

When activated, the RRT meets at a time and place specified by the Chair of the team. At activation, the RRT Chair designates a Public Information Officer (PIO) who is, in Utah, to be an EPA employee. The PIO coordinates all public information activities for the OSC and, upon special request, other official visitors.

In addition to a PIO, the Coast Guard has established a Public Information Assistance Team (PIAT) and, upon request of the OSC, the PIAT can provide assistance with public information during a pollution incident.

\subsection{PROTECTIVE ACTIONS}

Response actions include containment of the hazardous material, protection of threatened water supplies, and provision of disposal of removed materials. Protective actions include recommending to appropriate authorities the evacuation of threatened individuals and limiting access to the release area (with barricades, security fences, etc.). The ERT, an EPA team activated by the RRT with the help of the National Response Team (see Section 6), would be called in to help with technical assessment and equipment.

\subsection{HEALTH AND MEDICAL SERVICES}

The RRT would supplement local and state resources to assess and mitigate health effects with support provided through the DHHS. PHS physicians, nurses, public health advisors, and other personnel may be asked to assist in major incidents. Additional analytical support can be provided by the CDC.

Pursuant to the Superfund Amendments and Reauthorization Act (SARA) and Executive Order 12580, the ATSDR has responsibility for conducting health activities relating to the release of hazardous substances. The OSC may request ATSDR assistance by contacting the Region's ATSDR representative at any time during a removal action to obtain health advice if the release appears to present an imminent health threat. 


\subsection{MASS CARE}

The RRT would not have a role in mass care during response to an incid.nt. If temporary or permanent relocation of large segments of the population were necessary, FEMA would provide assistance.

\subsection{FIELD OPERATIONS/EMERGENCY WORKER EXPOSURE CONTROL}

Field sampling and assessment activities may be dore with the assistance of the ERT, which is available once the RRT has been activated.

Section 306 of the RCP indicates that the safety of all response personnel is to be ensured. Procedures include, generally, to proceed with extreme caution and to comply with all OSHA regulations.

\subsection{TRAFFIC AND ACCESS CONTROL} accident.

Generally, the RRT has no role in traffic and access control during the response to the

\subsection{PUBLIC INFORMATION}

Section 5.6 discusses public information personnel and procedures during an incident.

\subsection{ON-POST/OFF-POST INTERFACES}

Table 6 describes the interactions between TEAD and the RRT.

TABLE 6 On-Post/RRT Interfaces

\begin{tabular}{ll}
\hline RRT Position & \multicolumn{1}{c}{ Interface Description } \\
\hline EPA Co-Chair & Serves as point of contact between the OSC and RRT. \\
Member Agencies & $\begin{array}{l}\text { As required, provide technical assistance to the OSC } \\
\text { and off-post officials in the agencies' respective areas } \\
\text { of expertise. }\end{array}$ \\
\hline
\end{tabular}




\section{RESPONSE AND SUPPORT BY THE NATIONAL RESPONSE TEAM}

The NCP provides an organizational structure and procedures for preparing for and responding to discharges or releases of oil or hazardous substances. This section describes the provisions of the NCP that are pertinent to a potential chemical release at TEAD. The response to a release could include activation of the NRT.

\subsection{GENERAL CONCEPT}

The NRT is responsible for national planning and coordination to respond to oil and chemical discharges. The NRT consists of representatives from the U.S. Coast Guard, EPA, FEMA, DOD, DOE, USDA, DOC, DHHS, DOI, DOJ, DOL, DOT, DOS, Nuclear Regulatory Commission, and National Response Center (which includes the National Communications Center). Each agency has one or more representatives appointed to the team.

During an accident response, the Chair of the NRT is the member agency providing the OSC. The NRT is activated as an emergency response team when a release (1) exceeds the response capability of the region (in this case, Region VIII) in which it occurs, (2) transects regional boundaries, or (3) involves a significant threat to the public health and welfare or the environment. When activated (at the request of any member of the team), the NRT meets and evaluates reports from the OSC and the RRT, recommends a course of action, and makes requests to appropriate agencies (public or private) to provide needed resources, including equipment, personnel, or technical expertise.

\subsection{RESPONSE CAPABILITIES}

The NRT membership agencies provide expertise in numerous areas pertinent to the mission. For example, the DHHS has a special role in protecting the health of response workers and the public. It does so through both the ATSDR and the National Institutes for Environmental Health Sciences (NIEHS). The ATSDR provides medical care and testing of exposed individuals in cases of public health emergencies. The NIEHS is charged with providing specialized training to personnel who may be engaged in activities related to hazardous waste removal, containment, or emergency response.

The EPA, while not the Chair of the team in case of an accident at a DOD facility, would provide expertise on environmental effects of a release of hazardous substances and on pollution control techniques. The EPA can also provide legal expertise on the interpretation of environmental statutes and may enter into a contract or cooperative agreement with the state in order to implement a response action.

FEMA would provide advice and assistance to the lead agency on coordinating relocation assistance, including entering into a contract or cooperative agreement with the appropriate state or political subdivision.

The USDA has the scientific capability to measure, evaluate, and monitor, either on the ground or by use of aircraft, situations where natural resources (e.g., soil, water, wildlife, and vegetation) have suffered an adverse impact caused by hazardous substances. The USDA may 
be contacted through the Forest Service emergency staff officers who are designated members of the RRT. A number of the USDA's agencies can be called upon for assistance, including the SCS, the Animal and Plant Health Inspection Service (APHIS), and the Food Safety and Inspection Service (FSIS).

The SCS has personnel in nearly every county in the nation who are knowledgeable in soil, agronomy, engineering, and biology. These personnel can help to predict the effects of pollutants on soil and their movements over and through soils. Technical specialists can assist in identifying potential hazardous waste sites and provide review and advice on plans for remedial measures. The APHIS can assist in emergency response by controlling the movement of diseased or infected organisms to prevent the spread of contamination to unaffected areas. The FSIS can work with other federal and state agencies to establish acceptability criteria for slaughtering exposed or potentially exposed animals and destroying their products to prevent contaminated meat and poultry products from entering human food channels.

The DOI has extensive technical expertise available in its various bureaus and offices, including the Geological Survey (geology, hydrology, and natural hazards), the Bureau of Mines (analysis of inorganic hazardous substances relevant to site cleanup), the Office of Surface Mining (land reclamation), and the Bureau of Indian Affairs (coordination of activities on Indian lands).

The DOJ can provide expert advice on complicated legal questions arising from discharges or releases and federal agency responses. In addition, the DOJ represents the federal government, including its agencies, in litigation relating to such discharges or releases.

The DOL, through OSHA and state operating plans approved under Section 18 of the Occupational Safety and Health Act of 1970, has the authority to conduct safety and health inspections of hazardous waste sites to assure that employees are being protected and to determire if the site is in compliance with all other relevant regulations.

The DOT offers, through the Research and Special Programs Administration (RSPA), expertise in the requirements for packaging, handling, and transporting regulated hazardous materials.

\subsection{DIRECTION AND CONTROL}

As for the RRT, the EPA or Coast Guard usually provides the OSC at an incident site, but DOD designates the OSC on a DOD installation. If the NRT were to respond to an accident at TEAD, the OSC would not be the NRT DOD member, but would be the IRF Commander, or the SRF Commander after he or she has taken command. The DOD member would, however, be the Chair of the NRT for the incident.

\subsection{COMMUNICATIONS}

The National Response Center, located at Coast Guard headquarters, is the national communications center and is continuously staffed for handling activities related to response actions. The National Response Center acts as the single federal point of contact for all pollution incident reporting, including surety materials and munitions. Notice of a discharge must be 
made by a telephone call to a toll-free number or a special local number. Each telephone notice is recorded and manually entered into an on-line computer data base. The National Response Center tracks medium, major, and potentially major spills and provides incident summaries to all NRT members and other interested parties. The National Response Center evaluates incoming information and immediately advises FEMA of a potential major disaster or a need for evacuation.

\subsection{HAZARD ASSESSMENT}

The NRT relies primarily on the OSC or the RRT to assess the potential hazard to public health and welfare or the environment. The NRT does not participate in hazard assessment unless local and regional resources are overwhelmed. If, however, this does occur, then the appropriate member agency is called upon to assist the local and regional efforts in determining the nature and extent of the hazard. In the case of an accident at TEAD, the DOD would be most directly involved, and its cadre of technical experts on the effects of a release of chemical weapons would perform hazard assessment. In addition, it is possible that the EPA and DHHS, as well as the DOI and USDA, would become involved in hazard assessment activities, particularly during the recovery phase (see Section 6.2).

\subsection{ALERT AND NOTIFICATION}

As described in Section 6.4, the NRT maintains the National Response Center as a 24-hour communications center to receive notification of all types of spills of oil and hazardous materials. The Center then passes along this information to the appropriate agencies. These communications are by telephone.

\subsection{PROTECTIVE ACTIONS}

The NRT does not have a defined role in protective action decision-making. In the very unlikely event that the NRT takes control of the accident response, the NRT member that is the OSC would recommend protective actions.

\subsection{HEALTH AND MEDICAL SERVICES}

The NRT would make arrangements for the provision of resources for health and medical services in the event that local and regional resources were overwhelmed. The DHHS would probably be called upon for technical expertise and possibly for equipment. Arrangements for private resources with equipment closest to the accident site would be made.

\subsection{MASS CARE}

If the accident were on a scale that caused a Presidential Disaster Declaration, federal funds would be provided for disaster relief and FEMA would be brought in to make arrangements for housing, including relocation. 


\subsection{FIELD OPERATIONS/EMERGENCY WORKER EXPOSURE CONTROL}

Involvement of the NRT in field operations is unlikely. It is expected that Army personnel will tike samples for measuring contamination. However, as noted above (Section 6.5), other federal agencies may be called upon during the recovery phase to assist in assessing the extent of contamination and to help determine remedial activities.

Advice and assistance on the protection of emergency workers can be supplied by OSHA, most likely during the remediation phase.

\subsection{TRAFFIC AND ACCESS CONTROL}

The NRT would not participate in traffic and access control, except in the extremely unlikely event that the effects of an accident crossed regional boundaries, thus requiring traffic control beyond the jurisdiction of the state or the RRT.

\subsection{PUBLIC INFORMATION}

Except for notification (Section 6.6), the NRT does not have a public information role at the site of an incident unless an NRT member becomes the OSC, which is not expected to occur during an incident at TEAD.

\subsection{ON-POST/OFF-POST INTERFACES}

For an accident at TEAD, the main interface between on-post personnel and an NRT member would be between the OSC and the DOD NRT member, who would coordinate the provision of additional assistance requested by the OSC. 


\section{REENTRY AND RESTORATION}

This section describes agency responsibilities for restoration and recovery activities and identifies which resources and skills they would be able to bring to the process. The level of government called upon to assist with reentry and restoration would depend on the severity of the accident, its effects on property and the environment, and the complexity of the cleanup of the chemical agent that was released. The federal, state, and local government activities and responsibilities for reentry and restoration are described below.

\subsection{FEDERAL ASSISTANCE}

This section describes the role, responsibilities, and type of assistance that the federal sector (including military and civilian agencies or organizations) will provide during the reentry and restoration phase of a chemical accident.

\subsubsection{NRT/RRT Assistance}

The resources of the federal government become available for reentry and restoration through activation of the NRT. The means for activation and delineation of NRT member agencies are outlined in Section 6. The request for assistance with an accident at TEAD would come from the OSC (the SRF Commander or IRF Commander -- see Section 7.1.2). The EPA, which usually chairs the NRT, is likely to have a major role during the reentry and restoration phase.

The NCP requires remedial actions to be implemented as soon as site data and information make it possible to do so. Accordingly, the EPA has established a program goal and program management principles to assist in the identification and implementation of appropriate remedial actions. The program goal is to select remedies that are protective of human health and the environment, that maintain protection over time, and that minimize the quantity of untreated waste. Program management principles include selection of actions and techniques that achieve significant risk reduction quickly and that take the complexity of the whole problem into account.

The lead agency must characterize the nature of and threat posed by the hazardous substances and hazardous materials and gather data necessary to assess the extent to which the release poses a threat to human health or the environment or to support the analysis and design of potential response actions by conducting, as appropriate, field investigations to assess the following factors:

- Physical characteristics of the site, including important surface features, soils, geology, hydrogeology, meteorology, and ecology;

- Characteristics or classifications of air, surface water, and groundwater;

- The general characteristics of the waste, including quantities, state, concentration, toxicity, propensity to bioaccumulate, persistence, and mobility; 
- The extent to which the source can be adequately identified and characterized;

- Actual and potential exposure pathways through environmental media;

- Actual and potential exposure routes, for example, inhalation and ingestion; and

- Other factors, such as sensitive populations, that pertain to the characterization of the site or support the analysis of potential remedial action alternatives.

Using data developed as indicated above, the lead agency conducts a site-specific baseline risk assessment to characterize the current and potential threats to human health or the environment that may be posed by contaminants migrating to groundwater or surface water, entering the atmosphere, leaching through soil, remaining in the soil, and bioaccumulating in the food chain. The results of the baseline study will help establish acceptable exposure levels for use in developing remedial alternatives.

A feasibility study is conducted to ensure that appropriate remedial alternatives are developed and evaluated such that relevant information concerning the remedial action options can be presented to a decision-maker and an appropriate remedy selected. The resources of the various federal agencies can be called upon to help perform these analyses (see Section 6). Often, consultants are hired to help perform the work in a timely manner.

The above restoration process is described in detail in the NCP. While restoration of the immediate site is analyzed and alternatives are prepared, evacuees may or may not reenter the area, depending on the severity and extent of contamination. This would be measured by field sampling operations and safety of reentry determined on an ad hoc basis.

The role of the RRT is to provide technical assistance, help secure needed equipment, and help find disposal sites, if needed. The RCP lists cleanup services and suppliers for Region VIII.

\subsubsection{Department of the Army}

Reentry and restoration becomes a concern with the very first response to a chemical accident by the IRF. Throughout the response, data gathered by field teams is forwarded to restoration planners. Once the SRF is in place, a formal planning group is established for the express purpose of developing the Chemical Event Restoration Plan (CERP). After stabilization of the accident site, a decision regarding command of the restoration effort is made by Headquarters DA or the Commanding General of AMC.

The Restoration Planning Group, under the direction of the Restoration Planning Officer, reports to the Director for Special Staff and is responsible for the development of the CERP. Offpost technical representatives and officials participate in the Restoration Planning Group to develop the CERP. This participation is encouraged by the Army, but the extent of involvement of off-post officiais is not clear. For exampie, it is unclear whether off-post officials can specify the scope of the plan (e.g., levels for determining contamination). In the absence of previously 
agreed-upon levels for contamination and cleanup, it is expected that these types of issues will have to be worked out during the course of SRFX-91. The Restoration Planning Group receives contamination assessments from the Hazard Analysis Group. The personnel comprising the Restoration Planning Group are described below.

The CRDEC Liaison Team provides technical support to the Restoration Planning Group. As the primary experts on the properties of chemical agents, the Liaison Team is the source of information about the behavior of chemical agents in the environment.

The Safety Officer provides general and chemical safety guidance to the group and is the point of contact on all safety matters. This individual identifies the specific type of protective clothing needed by monitoring and cleanup teams. The Safety Officer is also responsible for the preparation and submittal of safety reports.

The Environmental Officer is the lead officer on all environmental actions. His or her duties include (1) assessing the extent of contamination by chemical agents, (2) developing an estimate of the impact of contamination on public facilities, and (3) assisting and providing guidance to installation environmental personnel.

Annex J (Recovery Operations) of the AMC CSRFCERP provides guidance and delineates responsibilities for restoring the installation and surrounding area in the event of a chemical accident. Complete recovery operations are to be described in two action plans: the monitoring plan and the restoration/remediation plan.

The monitoring plan identifies the following:

- Assumptions about areas of agreement among participants based upon available situational data and known population and personnel needs;

- The media to be sampled, criteria for collecting representative samples, and methods for sample collection;

- A sample tracking and transportation protocol;

- A mutually acceptable sample analysis method; and

- Procedures for providing for worker safety during environmental monitoring.

The process followed to develop the CERP is intended to systematically address the issues associated with restoring the accident area on post and affected surrounding areas off post to an acceptable condition. Among the many issues addressed are (1) the level to which areas and items will be cleaned; (2) the methods for handling contaminated water, air, soil, and structures; (3) what to do when acceptable cleanup is not possible; and (4) how to address public concerns and handle claims. These issues and other key components of the plan will be developed through coordination with the Deputy OSC and appropriate local, state, and federal agencies. An ad hoc committee of these and other officials, from federal agencies having statutory authority or responsibility for cleanup of affected areas, is to be formed to identify the "scope, policies, and concepts" that will be included in the CERP. All agencies involved in the development of the CERP will be co-signatories to the plan. 


\subsection{STATE ACTIVITIES}

As described in Section 4, the state does not have a current emergency response plan. Similarly, they do not have a reentry and restoration plan component specifically for chemical agents, but they expect to develop one after reentry and restoration guidance for the CSEPP is completed.*

The lead agency for the state of Utah during the reentry and restoration phase is the Utah Highway Patrol. Technical assistance is provided to the Highway Patrol by the Utah Department of Health and other state agencies as needed. The state may also be a natural resource trustee under the NCP. This would give the state the authority to carry out its own assessment and remediation of damage to its natural resources that could result from a chemical accident at TEAD. An analysis of applicable environmental laws and more information about the state's role is available in Appendix A.

\subsection{LOCAL ACTIVITIES}

The reentry and restoration component of the Tooele County EOP will be developed after the CSEPP reentry and restoration guidance is completed (see Section 7.2).

\footnotetext{
*The CSEPP is an Army-funded program, undertaken in cooperation with FEMA, to enhance the emergency preparedness of installations (with chemical surety missions) and the surrounding local communities and their respective states.
} 
58 
APPENDIX A:

ENVIRONMENTAL STATUTES, REGULATIONS, AND PERMIT REQUIREMENTS 


\title{
APPENDIX A: \\ ENVIRONMENTAL STATUTES, REGULATIONS, AND PERMIT REQUIREMENTS
}

This appendix identifies the major environmental laws, regulations, executive orders, and permits that would apply to a chemical accident at TEAD in Utah. Various federal and state environmental statutes impose environmental protection and compliance requirements upon DOD. Executive Order 12088 (43 Federal Register [FR] 47707, Oct. 13, 1978) requires federal agencies to comply with applicable administrative and proceaural pollution control standards established by, but not limited to, the Clean Air Act (42 United States Code [USC] 7401 et seq.), the Noise Control Act (42 USC 4901 et seq.), the Clean Water Act (33 USC 1251 et seq.), the Safe Drinking Water Act (42 USC 300(f) et seq.), the Toxic Substances Control Act (15 USC 2601, et seq.), and the Resource Conservation and Recovery Act (RCP.A) (42 USC 6901 et seq.). The Comprehensive Environmental Response, Compensation and Liability Act (CERCLA) (42 USC 9601-9675), as amended by the Superfund Amendments and Reauthorization Act of 1986 (SARA) [Public Law 99-499, 100 Stat. 1613 (1986)], and the NCP (40 CFR Part 300; 55 FR 8666, March 8. 1990; DOD Directive 5030.41) also apply to DOD facilities. The DOD must also comply with the statutes and regulations of Utah in coordinating the planning, response, reentry, and remediation of the facility during and after a chemical accident.

\section{A.1 CERCLA AND SARA}

\section{A.1.1 DOD Authority under CERCLA}

CERCLA specifies responsibilities and procedures to follow in the event of a release of a "hazardous substance," including specifications for long-term cleanup and restoration activities. EPA regulations define the term hazardous substance and provide lists of specific chemicals. ${ }^{*}$ The current definition includes only the mustard agents $H$, HD, and HT among the lethal chemical weapons stockpile; agent $L$ and the nerve agents are nut included. Thus, at the moment, a spill of agents L, GA, GB, or VX would not be subject to CERCLA notification and

"Specifically, the following definition of "hazardous substance" in 40 CFR $\S 300.5$ is relevant:

\begin{abstract}
"Hazardous substance as defined by section 101(14) of CERCLA, means: Any substance designated pursuant to section $311(\mathrm{~b})(2)(\mathrm{A})$ of the Clean Water Act; any element, compound, mixture, solution or substance designated pursuant to section 102 of CERCLA; any hazardous waste having the characteristics identified under or listed pursuant to section 3001 of the Solid Waste Disposal Act ... any toxic pollutant listed under section 307(a) of the CWA; any hazardous air pollutant listed under section 112 of the Clean Air Act; and any imminently hazardous chemical substances or mixture with respect to which the EPA Administrator has taken action pursuant to section 7 of the Toxic Substances Control Act."
\end{abstract}

Of the various lists of chemical provided in EPA regulations issued under these statutes, the only reference to chemical agents is in 40 CFR $\S 261$, Subpart D, Appendix VII, Listing of Hazardous Waste, which includes mustard gas (CAS 505-60-2). However, other agents are on the "Extremely Hazardous Substance List" published pursuant to the Emergency Planning and Community Right-to-Know Act (SARA, Title III) (Public Law 99-499) and therefore are subject to that statute's emergency notification reporting requirements (40 CFR Part 355). 
response requirements, but a release of $\mathrm{H}, \mathrm{HD}$, or HT would.* Therefore, the procedures outlined under this section are based on the assumption that CERCLA response authority applies.

Pursuant to Executive Order 12580, § 2(d) (52 FR 2923, Jan. 23, 1987), the functions vested in the President to initiate cleanups when there is an imminent and substantial danger to the public health or welfare [CERCLA $\S \S 104(\mathrm{a}),(\mathrm{b})$ and (c)(4), 113(k), 117(a) and (c), 119, and 121] are delegated to the Secretary of Defense with respect to releases or threatened releases where either the release is on or the sole source of the release is from any facility or vessel under the jurisdiction, custody, or control of the DOD. These functions, however, must be exercised consistent with the requirements of CERCLA $\$ 120$ concerning federal facilities. Thereunder, the Secretary has the power to conduct a removal action or a remedial action relating to the release into the environment of any pollutant or contaninant that may present an imminent and substantial danger to the public health or welfare, or take any other response measure consistent with the NCP that the Secretary deems necessary to protect the public health or welfare or the environment. The Secretary is authorized to undertake such investigations, monitoring, surveys, testing, and other information gathering as he or she may deem necessary or appropriate and may select the remedial actions in accordance with $\S 121 \mathrm{cf}$ CERCLA. Under CERCLA $\$ 113(\mathrm{k})$, the Secretary shall provide for the participation of interested persons in the development of the administrative record on which he will base the selection of such remedial actions. Before adoption of a remedial action plan, the Secretary must publish a notice and brief analysis of the proposed plan, and if a different plan is finally adopted, the Secretary shall publish an explanation of the significant differences and the reasons such changes were made.

Under $\S 103$ of CERCLA, any person in charge of a facility shall, as soon as he or she has knowledge of any release of a hazardous substance from such facility in quantities equal to or greater than those determined pursuant to $\S 102$ of CERCLA (40 CFR Part 302), immediately notify the National Response Center of such release. The National Response Center shall convey the notification expeditiously to all appropriate government agencies, including the Governor of Utah.

Pursuant to Executive Order 12580, $\$ 2$ (c)(1), the authority to carry out permanent relocation of residents, business, and community facilities or temporary evacuation and housing of threatened individuals under a $\$ 104(\mathrm{a})$ response action is delegated to the Director of FEMA. ${ }^{+}$Permanent or temporary relocation of individuals may be required during a 104(a) response being conducted by DOD after a health assessment by the ATSDR finds exposure presents a significant risk to human health. ${ }^{\ddagger}$

\footnotetext{
*However, see "Designation of Extremely Hazardous Substances as CERCLA Hazardous Substances," proposed rule, 54 FR 3388, January 23, 1989. According to 55 FR 16818, April 23, 1990, this rule is scheduled for finalization in November 1990.

${ }^{+}$Also see Memorandum of Understanding (MOU) between The Federal Emergency Maragement Agency and the EPA for the Implementation of CERCLA Relocation Activities Under P.L. 96-510, SDIC 9295.5-01.
}

$\ddagger$ Also see Health Assessments by the Agency for Toxic Substances and Disease Registry, SDIC 9285.4-03. 


\section{A.1.2 DOD Authority under SARA}

Under $\S 211$ of SARA, Congress established the Defense Environmental Restoration Program. The Restoration Program's scope is broader than the CERCLA \& 104 response authorities delegated to the Secretary of Defense. The Restoration Program also includes (1) the identification, investigation, research and development, and cleanup of contamination from hazardous substances, pollutants, and contaminants, (2) the correction of environmental damage (such as detection and disposal of UXO) that creates an imminent and substantial endangerment to the public health or welfare or to the environment, and (3) demolition and removal of unsafe buildings and structures under the jurisdiction of the Secretary of Defense. The Secretary is also responsible for and may enter into agreements on a reimbursable basis with any other federal agency or any state or local government agency for the identification, investigation and cleanup of any off-site contamination possibly resulting from the release of a hazardous substance or waste at a facility under the Secretary's jurisdiction (10 USC 2701).

SARA $\$ 211$ also requires the Secretary of Defense to notify the Secretary of Health and Human Services of the most commonly found unregulated hazardous substances at DOD facilities for which no standard, requirement, criteria, or limitation is in effect under the Toxic Substances Control Act, the Safe Drinking Water Act, the Clean Air Act, or the Clean Water Act (10 USC 2704). Thus, chemical weapon agents not commonly found in industrial or commercial hazardous chemical listings and not defined under those acts or RCRA can be incorporated into the response activities of the ATSDR under CERCLA \& 104(i).

The Restoration Program is to be carried out in consultation with the Administrator of the EPA, and DOD must notify the appropriate regional offices of EPA and state and local authorities of the discover: ' of releases, the extent of the contamination, proposals to address the contamination, and the commencement of each phase of any response action [10 USC 2705(a)]. DOD must given these agencies an opportunity to comment, uniess the action is a removal action "taken because of imminent and substantial endangerment to human health or the environment and consultation would be impractical" [10 USC 2705(b)]. Pursuant to 10 USC 2705(c), DOD is to establish technical review committees to review and comment on proposed response actions, including representatives from DOD, EPA, state and local agencies, and the public involved in the action.

\section{A.1.3 Removal or Remedial Actions}

The respu ise authority differs depending on if the site of the chernical accident is on the National Priority List (NPL) (42 USC 9r.05; 40 CFR 300.425). If the site is not on the NPL, the remedial action is subject to those authorities delegated to the Secretary of Defense under Executive Order 12580, SARA § 211, and the requirements of the NCP (40 CFR Part 300 et seq.), with the Secretary of Defense making the ultimate decision concerning the appropriate remedial action at the site. If the site is listed, $*$ additional requirements under CERCLA \$ 120(e) apply, setting forth schedules for completion of certain tasks, including the completion of a remedial investigation and feasibility study and the execution of an interagency agreement with the EPA for the expeditious completion of all necessary remediai actions at such facility. The Administrator of the EPA holds the ultimate power to select the remedial action applicable to

*Tooele Army Depot, North Area, was listed on the NPL in 55 FR 35502, August 30, 1990. 
an NPL site. Any remedial action or removal action carried out at the site of the chemical accident must comply with CERCLA $\S 121$ and the NCP.

\section{A.1.3.1 Removal Actions}

After giving notice under CERCLA $\S 103$ and performing the initial response action to the accident, pursuant to Subparts $B$ and $C$ of the NCP, the DOD must determine if removal actions are required. A removal action refers to cleanup or removal of released hazardous substances from the environment or the taking of such other actions as may be necessary to prevent, minimize, or mitigate damage to the public health or welfare or to the environment, which may otherwise result from the release. The term also includes security fencing or other measures to limit access; provision of alternative water supplies; temporary evacuation and housing of threatened individuals not otherwise provided for; the investigation, monitoring, surveying, testing, and other information gathering as necessary to identify the existence and extent of danger to the public health and welfare or the environment; post-removal site control, where appropriate; and any emergency assistance that may be provided under the Disaster Relief Act of 1974 (42 USC 5121). Removal actions must be carried out in accordance with the requirements set forth in $\S 300.410$ of the NCP.* Pursuant to $\S 300.525$ of the NCP, the EPA must consuit with Utah's Division of Environmental Health on all removal actions to be conducted in that state.

\section{A.1.3.2 Remedial Actions}

A remedial action is an action taken consistent with a permanent remedy to prevent or minimize the release of a hazardous substance so that it does not migrate to cause substantial danger to present or future public health and welfare or the environment. The term includes such on-site actions as storage or confinement; perimeter protection using dikes, trenches, or ditches; clay cover; neutralization; cleanup of released hazardous substances and associated contaminated materials; recycling or reuse; diversion; destruction; segregation of reactive wastes; dredging or excavatiuns; repair or replacement of leaking containers; collection of leachate and runoff; treatment or incineration; provision of alternative water supplies; any monitoring reasonably required to ensure that such actions protect the public health and welfare and the environment; and, where appropriate, post-removal site control activities. The term also includes the costs of permanent relocation of residents and business and community facilities where EPA determines that, alone or in combination with other measures, such relocation is more costeffective than, and environmentally preferable to, the transportation, storage, treatment, destruction, or secure disposition off site of such hazardous substances, or may otherwise be necessary to protect the public health and welfare (40 CFR 300.5). A remedial action can either be a follow-up to a removal action or can be initiated without a previous removal action where there is contamination posing a long-term hazard but no immediate danger ( 40 CFR § 300.420). The NCP requires that if the DOD determines that "the removal action will not fully address the threat posed by the release," then the DOD is to "ensure an orderly transition from removal to remedial action" [ 40 CFR $\S 300.415(\mathrm{f})$ ]. If there is no health risk associated with unrestricted use of the site of the spill, even by especially sensitive populations, there is no residual health risk

\footnotetext{
*Also see Environmental Review Requirements for Removal Actions, EPA 9318.0-05, and Removal Proceidures, Revision \#3, Superfund, SDIC 9360.0-03B.
} 
and a remedial action would not be necessary. Guidance on evaluating health risks associated with agent releases can be found in Oak Ridge National Laboratory (ORNL) and DHHS publications.*

Section 121 of CERCLA and $\S \S 300.420,300.430$, and 300.435 of the NCP address the standards any remedial action must meet. ${ }^{+}$Thereunder, remedial actions must comply with all legally applicable, relevant, and appropriate requiremients (ARARs) contained in federal environmental and siting statutes and regulations promulgated thereunder and with state environmental and siting statutes and regulations when they are more stringent than the federai statutes or regulations. Utah recently eriacted a law known as House Bill 57 that prohibits the Division of Environmental Health from enacting regulations more stringent than those required by the EPA, unless health concerns clearly indicate the need for such regulations. Utah's regulations are currently being amended to reflect the legislature's policy. Therefore, DOD should contact the Division of Environmental Health to ascertain if the hazardous waste involved has a more stringent state regulations. ARARs (and "to be considered" criteria) must be attained for hazardo's substances remaining on site at the completion of the remedial action. In addition, the implementation of the remedial action must aiso comply with ARARs to protect public health and the environment. $\ddagger$ ARARs are generally chemical-specific, location-specific, and action-specific. All federal and Utah statutes and promulgated statutes and regulations must be considered. For example, these standards include the following statutes, along with their appropriate rules and regulations:

- Clean Water Act

- Safe Drinking Water Act

- Floodplains Management and Wetlands Protection (Executive Orders 11988 and 11990)

- Toxic Substances Control Act

- Clean Air Act

" RCRA, as amended

- Utah Water Pollution Control Act (Utah Code Ann. §§ 26-11-1 to 26-11-20)

\footnotetext{
*Watson and Munro, Reentry Planning: The Technical Basis for Offsite Recovery Following Warfare Agent Contamination, ORNL-6628; Results of Workshop Meeting to Discuss Protection of Public Health and Sajety During Reentry into Areas Potentially Contaminated with Lethal Chemical Agent (GB, VX or Mustard Agent)," Draft 7/6/90, HHS, PHS, CDC.

'Also see Reiationship of The Removal and Remedial Program Undier the Revised National Contingency Plan, SDIC 9360.0-06A; Conducting Remedial Investigations/Feasibili y Studies : nder CERCLA, Guidance, EPA/540/G-89/004; Remedial Design and Remedial Action Guidance, SDIC 9355.0-C ŁA; Remedial Investigation/Feasibility Stuity Improtemtents, SDIC 9355.0-20; Remedial Investigation/Feasibility Study Improvements, Follow-Up, SDIC 9355.3-05; Re'medial Inie'stigation/ Feasibilitu Study Improvements Phase II. Streamlining Recommendation. SDIC 7355.3-06; Remedial Project Manager Primer, $\mathrm{EPA} / 540 / \mathrm{G}-87 / 005$; and Selection of Remedy, Interim Guidance on Superfund, SDIC 9355.0-19.
}

$\ddagger$ Also see Compliance with Applicable or Relevant and Appropriate Requirements, Interim Guitance, SDIC 9234.0-05. 
- Utah Safe Drinking Water Act (Utah Code Ann. $\S \S 26-12-1$ to 26-12-12)

- Utah Air Conservation Act (Utah Code Ann. §§ 26-13-1 to 26-13-30)

- Utah Solid and Hazardous Waste Act (Utah Code Ann. \$§ 26-14-1 to 26-14-23)

Section 121(f) of CERCLA provides that the Secretary of Defense must provide Utah with an opportunity to concur or not concur at least 30 days before the selection of a remedial action that does not attain an ARAR at a federal facility. If $U i$ in does not concur and desires to conform the remedial action to state requirements, the state may sue in federal court. If the state establishes that the decision is not supported by substantial evidence, based on the administrative record, the remedial action will be modified. If the state fails, the state has the option to pay the additional costs to conform the remedial action to the state requirements. Section 300.515 of the NCP sets forth the state involvement in a remedial action within the state. Such participation varies depending on the identify of the lead agency (i.e., DOD or EPA), the status of the site (i.e., NPL or non-NPL), and whether Utah becomes a support agency under the NCP.

\section{National Environmental Policy Act}

Pursuant to the National Environmental Policy Act (42 USC 4321 et seq.), all agencies of the federal government shall include in every recommendation or report on proposals for major federal actions significantly affecting the quality of the human environment, a detailed statement by the responsible official on the environmental impact of the proposed action, any adverse environmental effects that cannot be avoided, alternatives to the proposed action, and any irreversible and irretrievable commitments of resources involved in the proposed action. Under 32 CFR Part 651, the DA implements the Council on Environmental Quality regulations concerning NEPA implementation (40 CFR 1500 et seq.). Thereunder, the Assistant Secretary of the Army (Installations and Logistics) is the responsible official under NEPA. Heads of Headquarters DA agencies are to initiate the preparation of necessary environmental documentation. Pursuant to 32 CFR $\S 651.8$, the types of projects or actions requiring evaluation for environmental impact include installation restoration projects undertaken pursuant to $\S 104$ of CERCLA, incorporating the process described in the NCP.

In emergency situations following a chemical accident, such as containment and removal actions necessary for the protection of life or property, the Army may need to take immediate actions that have environmental impacts without making an environmental assessment. However, in such cases the Heads of Headquarters DA agencies must notify the Office of the Assistant Secretary of the Army for Installations and Logistics who will coordinate with the Assistant Secretary of Defense for Production and Logistics regarding the emergency action [32 CFR 651.9(b)]. A public affairs plan should be developed as soon as possible. These notifications apply only to actions necessary to control immediate effects of the emergency; other actions remain subjeci to NEPA review. 


\section{Occupational Safety and Health Act of 1970}

Pursuant to $\S 300.150$ of the NCP, all response actions shall comply with the provisions of response action worker safety and health set forth in the OSHA Standards for Hazardous Waste Operations and Emergency Response (29 CFR 1910.120). Thereunder, the DOD must make available an occupational safety and health program for the protection of workers at the response site consistent with such regulations. In addition, all general industry standards (29 CFR 1910) must be complied with where applicable.

\section{A.2 APPLICATION OF RCRA TO A CHEMICAL ACCIDENT}

\section{A.2.1 RCRA as an ARAR}

As set forth in Section A.1.3, RCRA can be an ARAR under CERCLA $\S 121$ and the NCP. RCRA requirements for treatment, storage, or disposal of hazardous wastes apply to a CERCLA site if the site contains RCRA listed or characteristic waste and the activity at the site during the remedial action constitutes current treatment, storage, or disposal. For instance, disposal occurs at a CERCLA site when wastes from different areas are consolidated into one area, waste is removed and treated outside and redeposited into the same or another area, or waste is picked up from one area and treated within another area of contamination and then redeposited into the initial area.

\section{A.2.2 RCRA Corrective Action}

The application of RCRA corrective action to federal facility removal or remedial sites is a more difficult issue. Section 120(i) of CERCLA provides that "nothing in this section shall affect or impair the obligation of any department, agency or instrumentality of the United States to comply with any requirement of RCRA (including corrective action requirements)." Pursuant to SARA $\S 211$, activities of the Restoration Program in dentifying, investigating, researching, and remediating contamination from hazardous substances shall be carried out subject to and in a manner consistent with CERCLA $\S 120$.

Utah, through its Division of Environmental Health, has authority to implement and enforce RCRA within the state; however, Utah has not yet been authorized to carry out corrective actions under RCRA $\S 3004$ (v) (off-site contamination). TEAD is such a facility, since it holds an interim status permit as a treatment, storage, or disposal facility. Under Utah Code Ann. (1953, as amended) $\S 26-14-8(8)$ (f) and Utah Admin. Code Rule 450-8-6.12, Lefore a permit may be issued, the Solid and Hazardous Wastes Committee shall require corrective action for all release of haz--ilous waste or constituents from any solid waste management unit at a treatment, storage, or disposal facility seeking a permit, regardless of the time at which waste was placed in such unit. Under Utah Admin. Code Rule 450-8-6.11, the Committee may require a corrective action to protect groundwater.

Utah has also been authorized to enforce RCRA $\S 3008(\mathrm{~h})$ corrective actions at facilities holding interim permits. Section $3008(\mathrm{~h})$ authority is broad in that unlike other sections of RCRA, §3008(h) addresses a release of "hazardous waste" rather than "hazardous waste identified or listed under Subtitle C." Therefore, the release of a hazardous chemical agent spill, 
even if not an identified or listed waste under RCRA, can still trigger a $\S 3008(\mathrm{~h})$ corrective action. A corrective action under $\S 3008(\mathrm{~h})$ can include containment, stabilization, or removal of the source of contamination; studies to characterize the nature and extent of the contamination; identification and evaluation of remedies; implementation of a remedy; and monitoring.

In general, if the site of the chemical accident was not a hazardous waste treatment, storage, or disposal facility licensed under RCRA, corrective actions as discussed above would not apply. However, the EPA has interpreted "solid waste management unit" broadly to include any waste management unit from which a hazardous constituent might migrate, irrespective of whether the units were intended for the management of solid or hazardous wastes (Pub. Law 98616 , Nov. 8, 1984). Also, the EPA interprets the language of $\S 3008(\mathrm{~h})$ to not require the finding that the release originated in a discernable waste management "unit," but from a facility authorized to operate under RCRA. Facility is interpreted to include the entire site and all contiguous property that is under control of the owner or operator engaged in hazardous waste management, i.e., the entire DOD base contiguous to the solid waste management unit holding a RCRA permit.* Therefore, a chemical spill site could require a corrective action even though the spill is not a hazardous waste identified or listed under RCRA and even though it did not originate from a permitted waste management unit.

The EPA, under $\$ 3004(\mathrm{v})$, may require such corrective actions to be taken beyond the facility boundary where necessary to protect human health and the environment unless the owner or operator of the facility concerned demonstrates to the satisfaction of Administrator that despite its best efforts, it was unable to obtain necessary permission to undertake such action. Such corrective actions are no longer limited to groundwater contamination (55 FR 30798, July 27, 1990, proposed rule).

Therefore, the implementation of corrective actions under Utah Code Ann. § 26-14-8(8)(f) or $\S 3004(v)$ of RCRA may compel the DOD to comply with other regulations in addition to CERCLA. The legislative history of SARA does not clarify this matter. Should the EPA or Utah decide to enforce a corrective action under these sections, such enforcement could curtail operations at an installation merely by withholding needed RCRA permits until a facility complied with all the requirements, regardless of the ongoing CERCLA action. ${ }^{+}$

\footnotetext{
*U.S. EPA Guidance, RCRA Section 3008(h), The Interim Status Corrective Action Authority, December 16, 1985.

${ }^{\dagger}$ Colorado v. United States Department of the Army, 707 F. Supp. 1562 (D. Colo. 1989), where the federal district court denied the Anmy's notion to dismiss the state's complaint under RCRA, citing $\leqq 120$ (i) to find CERCLA expressly requires the federal government to comply with RCRA and that the two statutes are not mutually exclusive or in conflict.
} 


\section{A.3 UTAH STATUTES AND POWERS}

\section{A.3.1 Hazardous Substances Mitigation Act}

The primary Utah legislation is the Hazardous Substances Mitigation Act [Utah Code Ann. (1953, as amended) $\S \S 26-14 d-101$ to 26-14d-801]. The Act requires that actions taken thereunder must be consistent with CERCLA. Utah, through its Department of Health, Division of Environmental Health, has the power to advise, consult, and cooperate with other agencies of the state, the federal government, and other states in carrying out its function to mitigate a hazardous release within the state of Utah. Thereunder, authorized personnel may enter and inspect any property, premises, or place where he or she has reason to believe there is a hazardous materials or substances release, to copy any records relating to those hazardous materials or substances, and to inspect and take samples of the suspected hazardous material or substances. Utah has additional authority to obtain information for investigation purposes if the release violates state water pollution control standards [\$ 26-11-14(1)] or air contaminants standards [§ 26-11-2(10)].

Further, if the director of the Division has reason to believe that any hazardous materials release is presenting a direct and immediate threat to public health or the environment, the director may issue an order requiring the owner or operator of the tacility to take abatement action within the time specified in the order. If the owner or operator is unwilling or unable to take abatement action, the director may use state monies to investigate the release and take abatement action. An abatement action means to take steps to eliminate or mitigate the direct or immediate threat to the public health or the environment caused by a hazardous materials release. Pursuant to rules and regulations promulgated by the Department of Health, in the event of a spill of hazardous waste or material that, when spilled, becomes hazardous waste, the person responsible for the material at the time of the spill shall immediately take appropriate action to minimize the threat to human health and the environment and notify the Utah State Department of Health, Division of Environmental Health, if the spill quantities exceeded specified levels (Utah Admin. Code Rule 450-9-1). The person responsible for the material at the time of the spill shall clean up all the spilled material and any residue or contaminated soil, water, or other material resulting from the spill or take such action as may be required by the Executive Secretary so that the spilled material, residue, contaminated soil, contaminated water, or other material no longer presents a hazard to human health or the environment. Within 15 days after any spill of hazardous waste or material is reported, the person responsible for the material at the time of the spill shall submit to the committee or the Executive Secretary a written report.

\section{A.3.2 Additional Department of Health Powers}

In addition, the Department of Health has the general power to investigate, enforce, and respond to public health hazards [Utah Code Ann. (1953, as amended) § 26-1-30]. Pursuant to the definition of a spill under Utah regulations, hazardous materials become hazardous waste when spilled (Utah Admin. Code Rule 450-9-1.). The state of Utah may bring an action under RCRA $\S 7002$ against any person to enforce the provisions of RCRA $\S 7003$ concerning the imminent and substantial endangerment to health or the environment from the past or present handling, storage, treatment, transportation, or disposal of any hazardous waste. Pursuant to SARA $\S 310$, the state of Utah also has the power to bring an action against the DOD to enforce 
the provisions of CERCLA. The executive director of the Department of Health has authority to abate a public health hazard if he or she finds that a condition exists that creates a clear present hazard to the public health and that requires immediate action to protect human health or safety, the executive director with the concurrence of the governor may order persons causing or contributing to such condition to reduce, discontinue, or ameliorate it to the extent that the public health hazard is eliminated [Utah Code Ann. (1953, as amended) § 26-1-12]. Under Utah law, there are no barriers to enforcement of Utah hazardous materials laws against the federal government. The definition of "facility" from which a release occurs includes any building, structure, installation, etc. or any site or area [Utah Code Ann. (1953, as amended) § 26-14d102(6)(a)].

\section{A.3.3 Utah Emergency Management Act}

Under the Utah Emergency Management Act, a Division of Comprehensive Emergency Management is established within the Department of Public Safety. The division has prepared and maintains programs and plans to provide for prevention and minimization of injury and damage caused by disasters, prompt and effective response to and recovery from disasters, identification of areas particularly vulnerable to disasters, coordination of hazard mitigation and other preventive and preparedness measures designed to eliminate or reduce disasters, assistance to local officials in designing local emergency action plans, coordination of federal, state, and local emergency activities, coordination of emergency operations plans with emergency plans of federal government, and the coordination of rapid and efficient communications in times of emergency.

The Act also creates a Disaster Emergency Advisory Council for the purpose of providing advice to the governor on matters relating to state government emergency disaster response and recovery actions and activities. The Council is composed of the lieutenant governor, attorney general, president of the Senate, speaker of the House of Representatives, and the directors of the Department of Public Safety, Division of Comprehensive Emergency Management, the Building Board, the Budget Office, the Department of Transportation, the Department of Social Service, the Department of Health, the Department of Community and Economic Development, the Department of Natural Resources, the National Guard, the Commissioner of Agriculture, the State Planning Coordinator, and representatives from two statewide, nongovernmental service organizations. The Commissioner of Public Safety is the Chairman of the Council.

The Act also creates the Hazardous Chemical Emergency Response Commission for the purposes of carrying out all requirements of the federal Emergency Planning and Community Right to Know Act of 1986. The Commission consists of the executive director of the Department of Public Safety and the executive director of the Department of Health. The Department of Public Safety has primary responsibility for all emergency planning activities, including preparation of policy and procedure and promulgation of rules necessary for implementation of the federal Emergency Planning and Community Right to Know Act of 1986. The Department of Health has primary responsibility for receiving processing, and managing hazardous chemical information and notifications under the federal Act. The Commission shall appoint a local planning committee for each local planning district that it establishes. Although the Emergency Planning and Community Right to Know Act of 1986 does not apply to federal 
agencies, Utah law extends the requirements of the federal Act pertaining to notification and submission of information to federal agencies, departments, installations, and facilities located in the state. Therefore, a party responsible for a hazardous substance spill must contact the State Emergency Response Commission, through the Utah Division of Environmental Health. ${ }^{\dagger}$

\section{A.3.4 Disaster Response and Recovery Act}

Pursuant to the Disaster Response and Recovery Act [Utah Code Ann. (1953, as amended) $\S 63-5$ a et seq.], a "local emergency" may be declared by proclamation of the principal executive officer of a political subdivision. Such declaration is official recognition that a disaster situation exists within the affected political subdivision and provides legal basis for requesting and obtaining state or federal government disaster assistance. After the proclamation of a local emergency, if the Governor of Utah finds a disaster has occurred or the occurrence of threat of a disaster is imminent in any area of the state, he or she may declare a "State of Emergency." During a State of Emergency, the governor is authorized and empowered to recommend and advise the evacuation of all or part of the population from any stricken or threatened area within the state if necessary for the preservation of life; recommend routes, modes of transportation, and destinations in connection with evacuation; suspend or limit the sale, dispensing, or transportation of alcoholic beverages, explosives, and combustibles; control ingress and egress to and from a disaster area and the movement of persons within the area; and recommend the occupancy or evacuation of premises in a disaster area.

During a State of Emergency, the Governor is commander-in-chief of the military forces of the state [Utah Constitution, Art. VII, § 4 and Utah Code Ann. (1953, as amended) § 39-1]. The Governor also has authority to call upon the Utah Highway Patrol to respond to the emergency [Utah Code Ann. (1953, as amended) § 27-10-4].

\section{A.4 LOCAL AUTHORITY}

Local entities can only act in accordance with delegated authority from the state legislature [Utah Constitution Art. XI, $\$ 5$ and Utah Code Ann. (1953, as amended) $\S 17-5-35$ ]. Further, if a hazardous substance site is on state or federally owned land, then local zoning, building, and planning laws would be inapplicable to that site [Utah Code Ann. (1953, as amended) § 10-9-29]. Therefore, for spills at a DOD-owned site, the Department of Health and other executive agencies of the state would retain jurisdiction.

*The definition of person under SARA does not include federal agencies [see 40 CFR 300.405(g)].

${ }^{+} 288$ North 1460 West, P.O. Box 16690, Salt Lake City, Utah 84116-0690, (801) 538-6121 (Title III spills) and (801) 538-6333 (all spills). 


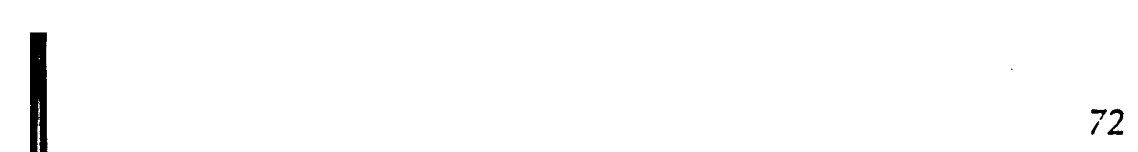


APPENDIX B:

SOURCES OF INFORMATION 


\section{APPENDIX B:}

\section{SOURCES OF INFORMATION}

\section{B.1 EMERGENCY PLANS}

National Oil and Hazardous Substances Pollution Contingency Plan (NCP), 40 CFR Part 300, 55 FR 8666, March 8, 1990.

Region VIII Oil and Hazardous Substances Pollution Contingency Plan (RCP), September 1990.

State of Utah Emergency Operations Plan, interim draft, March 11, 1991.

State of Utah Chemical Stockpile Emergency Preparedness Program (CSEPP), Appendices to State of Utah Emergency Operations Plan, Volume 2, Natural Disaster, interim draft, February 26, 1991.

Tooele Army Depot Disaster Control Plan (TEAD-DCP), Annex C, Chemical Accident/Incident Response and Assistance Plan (CAIRAP), draft, September 12, 1990.

Tooele County Emergency Operations Plan, CSEPP Annexes, draft, September 19, 1990.

U.S. Army Materiel Command (AMC) Chemical Service Response Force Commander's Emergency Response Plan (CSRFCERP), draft, undated.

\section{B.2 FEDERAL STATUTES AND REGULATIONS}

Comprehensive Environmental Response, Compensation and Liability Act (CERCLA), 42 USC 9601-9675, as amended by the Superfund Amendments and Reauthorization Act of 1986 (SARA), Pub. Law 99-499, 100 Stat. 1613 (1986).

Executive Order 12088, 43 FR 47707, October 13, 1978.

National Environmental Policy Act, 42 USC 4.321 et seq.

Resource Conservation and Recovery Act (RCRA), 42 USC 6901 et seq.

\section{B.3 UTAH STATUTES}

Disaster Response and Recovery Act, Utah Code Ann. (1953, as amended) $§ 63-5 a$ et seq.

Hazardous Substances Mitigation Act, Utah Code Ann. (1953, as amended) §§ 26-14d-101 to 26-14d-801. 
APPENDIX C: ABBREVIATIONS 


\section{APPENDIX C:}

\section{ABBREVIATIONS}

$\begin{array}{ll}\text { ACAICO } & \text { Assistant Chemical Accident/Incident Control Officer } \\ \text { AMC } & \text { U.S. Army Materiel Command } \\ \text { AMCCOM } & \text { U.S. Army Armament, Munitions and Chemical Command } \\ \text { AMCPA } & \text { U.S. Army Materiel Command Public Affairs } \\ \text { AOC } & \text { Army Operations Center } \\ \text { APHIS } & \text { Animal and Plant Health Inspection Service } \\ \text { AR } & \text { Army Regulation } \\ \text { ARC } & \text { American Red Cross } \\ \text { ARAR } & \text { applicable, relevant, and appropriate requirement } \\ \text { ATSDR } & \text { Agency for Toxic Substances and Disease Registry } \\ & \\ \text { BIA } & \text { Bureau of 'ndian Affairs } \\ \text { CA/I } & \text { Chemical Accident/Incident } \\ \text { CAICO } & \text { Chemical Accident/Incident Control Officer } \\ \text { CAIRA } & \text { Chemical Accident/Incident Response and Assistance } \\ \text { CAIRAP } & \text { Chemical Accident/Incident Response and Assista: -e Plan } \\ \text { CAMDS } & \text { Chemical Agent Munitio.ns Disposal System } \\ \text { CAMEO } & \text { Computer-Aided Managetinent of Emergency Operations } \\ \text { CDC } & \text { Centers for Disease Control } \\ \text { CEM } & \text { Comprehensive Emergency Management } \\ \text { CERP } & \text { Chemical Event Restoration Plan } \\ \text { CERCLA } & \text { Comprehensive Environmental Response, Compensation and Liability Act } \\ \text { CFR } & \text { Code of Federal Regulations } \\ \text { CPD } & \text { Combat Pictorial Detachment } \\ \text { CRDEC } & \text { Chemical Research, Development and Engineering Center } \\ \text { CS } & \text { Chief of Staff } \\ \text { CSDP } & \text { Chemical Stockpile Disposal Program } \\ \text { CSEPP } & \text { Chemical Stockpile Emergency Preparedness Program } \\ \text { CSRFCERP } & \text { Chemical Service Response Force Commander's Emergency Response Plan } \\ & \end{array}$

DA

Department of the Army

DCSOPS

DESCOM

Deputy Chief of Staff for Operations

DHHS

DOC

DOD

DOE

DOI

DOJ

DOI

DOS

DOSC

DOT

U.S. Army Depot System Command

Department of Health and Human Services

Department of Commerce

Department of Defense

Department of Energy

Department of tine Interior

Department of Justice

Department of Labor

Department of State

DSRFC

Deputy On-Scene Coordinator

Department of Transportation

Deputy Service Response Force Commander 


\begin{tabular}{|c|c|}
\hline EBS & Emergency Broadcasting System \\
\hline ECL & Emergency Classification Level \\
\hline EMS & Emergency Medical Services \\
\hline EOC & Emergency Operations Center \\
\hline EOD & Explosive Ordnance Disposal \\
\hline EOP & Emergency Operations Plan \\
\hline EPA & U.S. Environmental Protection Agency \\
\hline ERT & Environmental Response Team \\
\hline FAA & Federal Aviation Administration \\
\hline FCP & Field Command Post \\
\hline FCS & Forward Control Site \\
\hline FEMA & Federal Emergency Management Agency \\
\hline FORSCOM & U.S. Army Forces Command \\
\hline FR & Federal Register \\
\hline FSIS & Food Safety and Inspection Service \\
\hline HAZMET & Meteorological Hazard Specialist \\
\hline HSC & Health Services Command \\
\hline IRF & Initial Response Force \\
\hline IRFC & Initial Response Force Commander \\
\hline IRP & Installation Restoration Plan \\
\hline IRZ & Immediate Response Zone \\
\hline JHEC & Joint Hazard Evaluation Center \\
\hline JIC & Joint Information Center \\
\hline MET & Meteorological Detection Team \\
\hline $\mathrm{MOA}$ & Memorandum of Agreement \\
\hline $\mathrm{NCO}$ & Non-Commissioned Officer \\
\hline NCP & National Oil and Hazardous Substances Pollution Contingency Plan \\
\hline NDA & National Defense Area \\
\hline NIEHS & National Institutes for Environmental Health Sciences \\
\hline NOAA & National Oceanic and Atmospheric Administration \\
\hline NPL & National Priority List \\
\hline NRC & National Response Center \\
\hline NRT & National Response Team \\
\hline NWS & National Weather Service \\
\hline OASD(PA) & Office of the Assistant Secretary of Defense (Public Affairs) \\
\hline OPCP & Off-Post Command Post \\
\hline OSC & On-Scene Coordinator \\
\hline OSHA & Occupational Safety and Health Administration \\
\hline PAO & Public Affairs Officer \\
\hline PAR & Protective Action Recommendation \\
\hline PAZ & Protective Action Zone \\
\hline PHS & Public Health Service \\
\hline
\end{tabular}


PIAT Public Information Assistance Team

PIO Public Information Officer

RACES Radio Amateur Communications Emergency System

RCP Regional Oil and Hazardous Substances Pollution Contingency Plan

RCRA Resource Conservation and Recovery Act

RRT Regional Response Team

RSPA Research and Special Programs Administration

SARA Superfund Amendments and Reauthorization Act

SCS Soil Conservation Service

SOP standard operating procedure

SRF Service Response Force

SRFC Service Response Force Commander

SRFC/OSC Service Response Force Commander/On-Scene Coordinator

SRFCS

SRFX

Service Response Force Commander's Staff

SSCC Site Security Control Center

TEAD Tooele Army Depot

TEAD-DCP Tooele Army Depot Disaster Control Plan

TEU Technical Escort Unit

TRADOC U.S. Army Training and Doctrine Command

USAISC U.S. Army Information Systems Command

USC United States Code

USDA

U.S. Department of Agriculture 

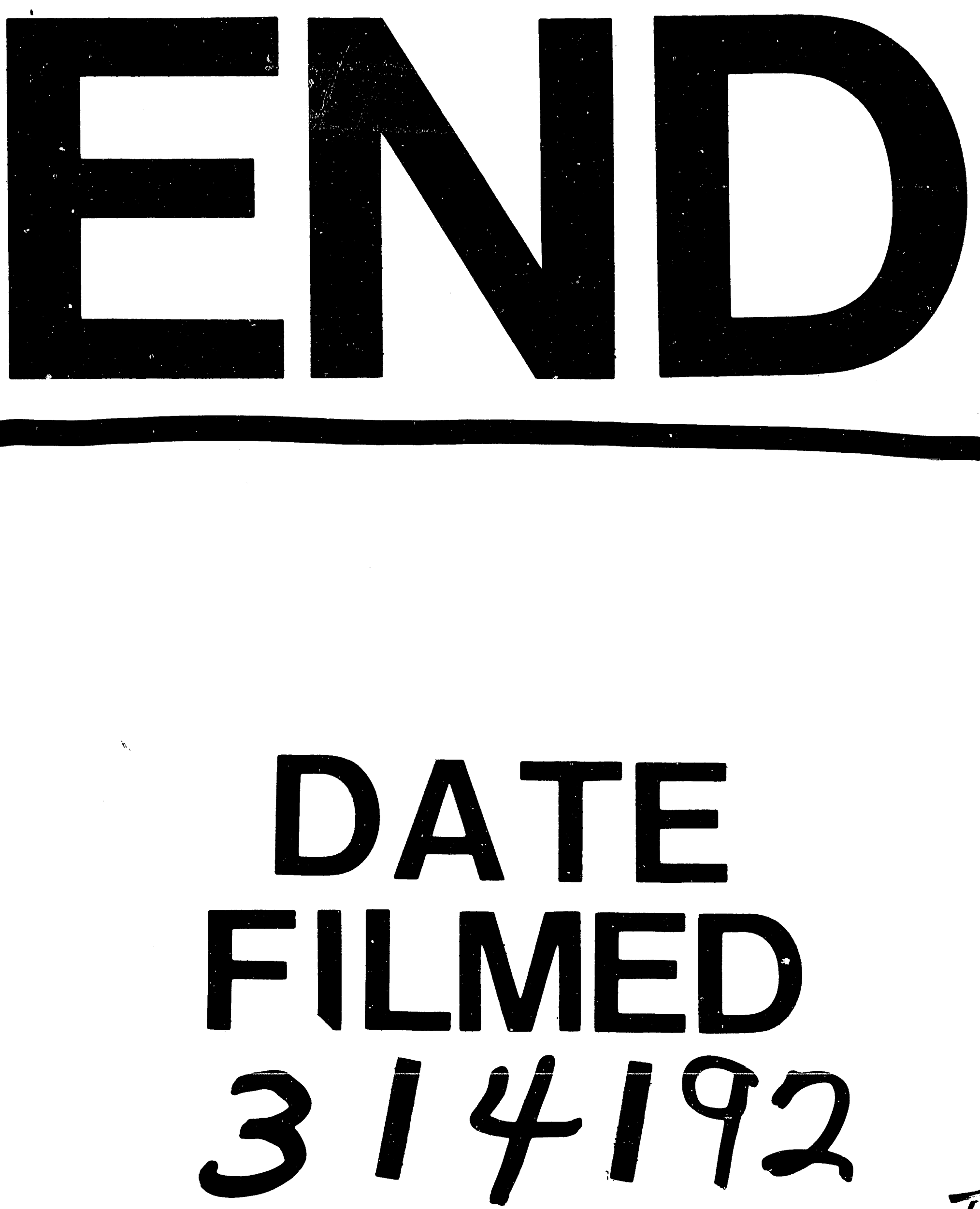

$I$ 


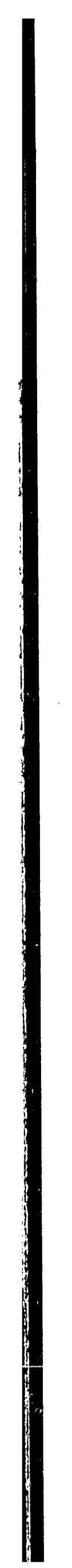

